\title{
The Effectiveness of Provider Training to Improve Compliance with Use of Written Asthma Action Plans in the Care of Patients with Asthma
}

Mary Sizemore

West Virginia University

Follow this and additional works at: https://researchrepository.wvu.edu/etd

\section{Recommended Citation}

Sizemore, Mary, "The Effectiveness of Provider Training to Improve Compliance with Use of Written Asthma Action Plans in the Care of Patients with Asthma" (2014). Graduate Theses, Dissertations, and Problem Reports. 311.

https://researchrepository.wvu.edu/etd/311

This Dissertation is protected by copyright and/or related rights. It has been brought to you by the The Research Repository @ WVU with permission from the rights-holder(s). You are free to use this Dissertation in any way that is permitted by the copyright and related rights legislation that applies to your use. For other uses you must obtain permission from the rights-holder(s) directly, unless additional rights are indicated by a Creative Commons license in the record and/ or on the work itself. This Dissertation has been accepted for inclusion in WVU Graduate Theses, Dissertations, and Problem Reports collection by an authorized administrator of The Research Repository @ WVU.

For more information, please contact researchrepository@mail.wvu.edu. 
The Effectiveness of Provider Training to Improve Compliance with Use of Written Asthma Action Plans in the Care of Patients with Asthma

\title{
Mary Sizemore
}

Doctoral Research Project submitted to the School of Nursing at West Virginia University in partial fulfillment of the requirements for the degree of

Doctorate in Nursing Practice

\author{
Gina Maiocco, Ph.D., RN, CCNS, Chair \\ Emily Barnes, DNP, FNP-C, Co-Chair \\ Holly Freed, MD \\ Department of School of Nursing
}

Morgantown, West Virginia

2014

Keywords: Asthma, Action Plan, Provider Training

Copyright 2014 Mary Sizemore 


\section{ABSTRACT \\ The Effectiveness of Provider Training to Improve Compliance with Use of Written Asthma Action Plans in the Care of Patients with Asthma}

Mary Sizemore

Background/problem statement: In 2010, asthma affected 25.7 million people in the United States including 7 million children (Centers for Disease Control and Prevention [CDC], 2012). The clinical problem was providers and nurses were not documenting the use of asthma action plans in the care of patients with asthma at a rural health clinic in Wirt County, West Virginia. Purpose: The purpose of this capstone project was to implement and evaluate a healthcare provider and nursing staff practice change related to the process of implementing training and asthma action plans for pediatric and adult patients with asthma.

Project Description with Procedures: The project plan included the following objectives (1) providers and nursing staff attended one educational session based on the PACE program regarding the use of action plans and learn about asthma management; (2) the team implemented asthma action plans based on the process change (3) pre/post knowledge testing scores were reviewed to identify the degree of change in practice.

Summary of Findings: The goal of a $10 \%$ increase in the implementation of asthma action plans was not met. There was a $4 \%$ increase in the documentation rate of asthma action plans in the post-implementation sample, but it was not statistically significant $(\mathrm{p}=0.153)$. Neither the documentation rate of the components of the action plan or the healthcare provider knowledge on asthma was statistically significant.

Implications: Success of future projects is dependent upon commitment from providers and nurses involved in the practice change. Because paper format was used in this project, future processes focused on improving documentation should utilize electronic charting to be more effective. 


\section{TABLE OF CONTENTS}

BACKGROUND AND SIGNIFICANCE OF PROJECT .................................

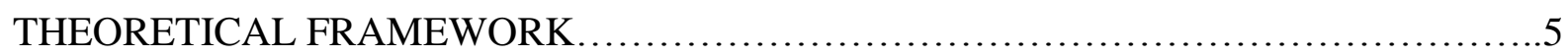

LITERATURE REVIEW AND SYNTHESIS.........................................11

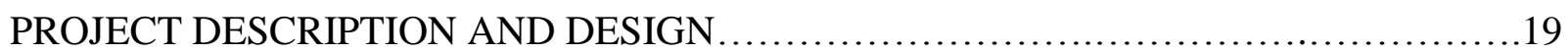

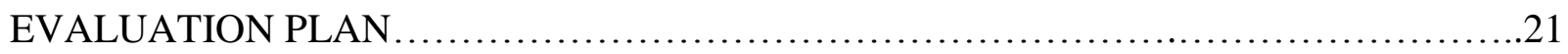

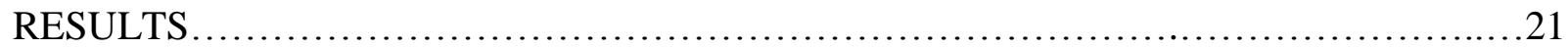

DISCUSSION AND RECOMMENDATIONS.........................................23

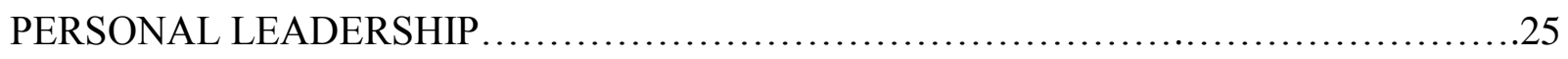

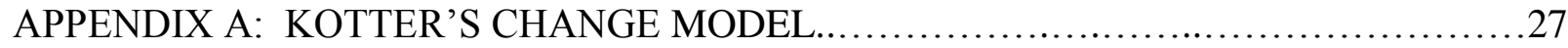

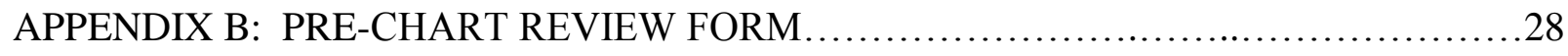

APPENDIX C: PRE/POST EDUCATION TEST .......................................... 30

APPENDIX D: PACE PROGRAM POWERPOINT ......................................... 31

APPENDIX E: USING A PEAK FLOW METER HANDOUT ............................... 38

APPENDIX F: ADULT ASTHMA ACTION PLAN ........................................40

APPENDIX G: STUDENT ASTHMA ACTION PLAN .................................41

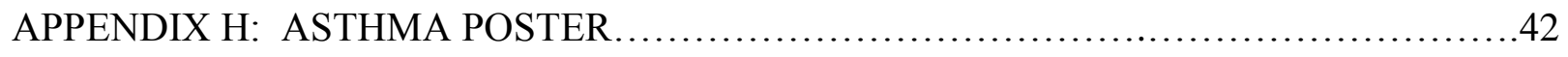

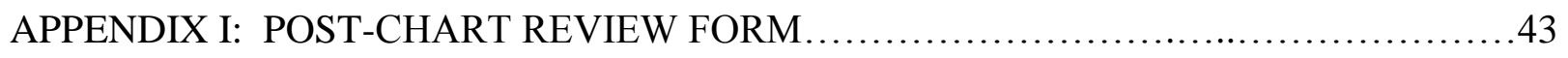

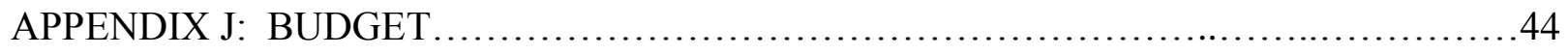

APPENDIX K: SMART OBJECTIVES..............................................

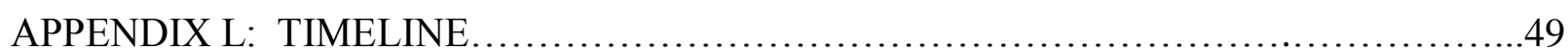

APPENDIX M: ASTHMA PRETEST/POSTTEST RESULTS..............................50

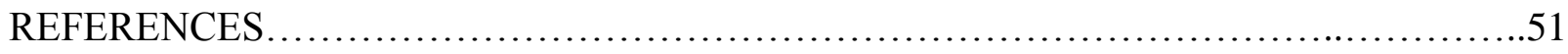


The effectiveness of provider training to improve compliance with use of written asthma action plans in the care of patients with asthma

Asthma is a chronic disease of the respiratory system. Although asthma management can be effective with current medical treatments, the prevalence of exacerbations continues to be a problem because patients lack the necessary tools to self-manage their disease process (Akinbami, 2006). The effective management of asthma involves the use of tools such as daily controller medications, rescue medications for exacerbations, recognition of triggers, and symptom monitoring (Akinbami, Moorman, \& Liu, 2011). Providers should also be educated on tools such as asthma action plans to help patients improve their asthma self-management (National Asthma Education and Prevention Program [NAEPP], 2007).

\section{Background and Significance}

In 2010, asthma affected 25.7 million people in the United States including 7 million children (Centers for Disease Control and Prevention [CDC], 2012). In the last 10 years, the diagnosis of asthma has increased by $15 \%$ in the United States (CDC, 2012). In 2009, asthma accounted for 1.9 million emergency department encounters, 8.9 million visits to provider offices, 479,300 hospitalizations, and 3,388 deaths (CDC, 2012).

In recent years, asthma deaths in children have declined but accurate diagnosis of asthma in medical records and patient self-management have not improved (Akinbami, 2006). It is a standard of care expectation that healthcare providers educate patients on self-management skills required to control their asthma symptoms at home. According to the clinical practice guidelines for the treatment of asthma, action plans are the recommended method of facilitating patient self- 
management of the disease (NAEPP, 2007). The written plan should be evaluated at each visit and updated as needed (NAEPP, 2007).

Research studies have identified benefits and contraindications to using asthma action plans. Gaps remain in the literature. Inconsistencies exist in the implementation of the action plan to include symptom focus, peak flow meter readings, depth of patient instruction, and receipt of the action plan by the patient (NAEPP, 2007; Bartholomew, Sockrider, Abramson, Swank, Czyzewski, Tortolero \& Tyrrell, 2006; Burkhart, Rayens, Revelette, \& Ohlmann, 2007; Huang and Wang, 2009; Sockrider, Abraham, Brooks, Caviness, Pilney, Koerner, \& Macias, 2006; Zemek, Bhogal, \& Ducharme, 2008; Wolf, Guevara, Grum, Clark, \& Cates, 2002). The benefits to using an action plan include earlier treatment of symptoms to prevent acute exacerbations and a partnership between the provider, nurse, and patient to improve health outcomes (NAEPP, 2013).

In 2010, West Virginia had approximately $11 \%$ of both children and adults diagnosed with asthma in their lifetime (West Virginia Asthma Education Prevention Program [WVAEPP], 2013). Approximately $6.5 \%$ of children and $7.3 \%$ of adults have a current diagnosis of asthma in West Virginia (WV-AEPP, 2013). West Virginia has also ranked in the top five states for asthma diagnosis over the last seven years (West Virginia Department of Health and Human Resources [WVDHHR], 2007). In Wirt County, West Virginia, where the project took place, the prevalence of asthma is $8.4 \%$, which is slightly below the state levels (WVDHHR, 2007). However, other risk factors exist that increase asthma related morbidity, mortality, and negative asthma related outcomes (WV-AEPP, 2013). In Wirt County, 19.2\% of the population lives below the poverty level and $17.2 \%$ of the population is without health insurance (WVDHHR, 
2007). In addition to those risk factors, approximately $25.1 \%$ of the population smokes cigarettes while $32.5 \%$ are classified as being obese.

\section{Financial Impact}

The financial burden of asthma related complications is staggering. In the United States, the annual cost of asthma related healthcare was $\$ 56.0$ billion (American Lung Association [ALA], 2012). Approximately $10 \%$ of the annual cost, or $\$ 5.9$ billion, was a result of lost productivity (ALA, 2012). The cost of asthma in the United States between 2002 through 2007 was $\$ 3,300$ per person, including medical expenditures, decreased productivity, and death (American Academy of Allergy Asthma and Immunology [AAAAI], 2013). In 2008, asthma was responsible for children missing 14.4 million school days (ALA, 2012). Adults missed 14.2 million days of work (ALA, 2012). Approximately 59\% of children and 33\% of adults with asthma who had an asthma exacerbation missed school or work in 2008 (AAAAI, 2013).

In West Virginia, the burden of asthma on Medicaid and CHIPs programs is continuing to increase. In 2005, West Virginia Children's Health Insurance Program (CHIP) reimbursed more than $\$ 1.8$ million for asthma-related services including provider encounters and medication (WVDHHR, 2007). Costs for asthma hospitalization in the state have increased from $\$ 10.3$ million in 1996 to \$23.2 million in 2005 (WVDHHR, 2007). In 2010, charges for asthma related hospital admissions exceeded \$29 million in West Virginia (WV-AEPP, 2013). According to the WV-AEPP (2013), in 2010 children less than 15 years of age were hospitalized more often than adults due to asthma complications. Financial data specific to Wirt County was not available at the time of this project.

\section{Statement of the Problem}


The problem is the providers and nurses at the Wirt County clinic were not documenting the use of asthma action plans in the care of patients with asthma, which was a failure to follow the standards of care in asthma management. The organization, which serves patients in Wirt, Wood, and Jackson Counties in West Virginia and Meigs County, Ohio, has approximately 500 patients with a diagnosis of asthma (Wirt County Health Services Association [WCHSA], 2013). In the six months prior to the process change, 56 patients received treatment for asthma related issues at the Wirt County site (WCHSA, 2013). One organization system issue affecting the use of the current EMR asthma action plan is that the form was difficult for providers and nurses to fill out. The plan required medications be typed into the system and the current EMR action plan form did not provide patients with adequate instructions. The Director of Clinical Services (DCS) attempted to update the EMR action plan but the system was unable to process the changes. The lack of information technology (IT) onsite added to the unsuccessful update within the system. The purpose of this paper is to describe the implementation and evaluation of a healthcare provider (Medical Doctor [MD], Family Nurse Practitioner [FNP], Physician Assistant [PA]) and nursing staff (Licensed Practical Nurse [LPN], Registered Nurse [RN], Medical Assistant [MA]) practice change related to the process of implementing Physician Asthma Care Education (PACE) based asthma action plans for pediatric and adult patients with asthma. The question this project addressed was: Does the use of provider and nurse education related to asthma management based on the PACE curriculum increase the utilization of written asthma action plans in pediatric and adult patients diagnosed with asthma at a rural health clinic in Wirt County, West Virginia? 


\section{Theoretical Framework}

Kotter's 8-step process for leading change provides the framework for this Doctor of Nursing Practice capstone project. According to Kotter (1995), the eight steps of the model are:

1. Establishing a sense of urgency

2. Forming a powerful guiding coalition

3. Creating a vision

4. Communicating the vision

5. Empowering others to act on the vision

6. Planning for and creating short -term wins

7. Consolidating improvements and producing still more change

8. Institutionalizing new approaches.

John Kotter's change model was developed from years of research and observations of failing businesses (Kotter, 1995). His research was based on the premise that almost all business related changes fail because the change is not realized throughout the organization (Kotter, 2012). A table outlining the model is located in Appendix A.

\section{Establishing a Sense of Urgency}

The first step of Kotter's change model is establishing a sense of urgency (Kotter, 1995). For this project, a sense of urgency was accomplished by discussing the fiscal, legal, and health ramifications of not adhering to standards of care. Following Institutional Review Board (IRB) for the protection of human subjects approval, a chart audit spanning 6 months prior to the education program was conducted to identify how many action plans were documented at baseline (Appendix B). Due to lack of charts meeting recruitment criteria timeframe for pre and 
post chart reviews, the protocol was amended with IRB approval to span 9 months.

Consideration was also given if provider notes included the following key elements of an asthma action plan: peak flow, symptom severity, medication frequency and dose, triggers, patient education, and plan adjustment. Data obtained from pre-education chart audits was used to establish urgency with the team by revealing the lack of compliance with guidelines and to inform the project director on the current clinical practices. Based on the number of patients seen per year at the clinic, the sample total of 100 charts, 50 pre education and 50 post education were reviewed to determine program effectiveness. See appendix B for the preprocess chart audit form.

\section{Forming a Powerful Guiding Coalition}

The second step of the model is to form a powerful guiding coalition. Kotter defines the coalition as a group with enough power to lead change (Kotter, 1995). For this capstone, approval of the project by the Chief Executive Officer (CEO), office manager, medical director (MDS), and clinical management coordinator ( $\mathrm{RN})$ accomplished forming a guiding coalition. The CEO was the ultimate authority on permission to implement the change process. The Clinical Management Coordinator was a registered nurse with experience in management of chronic disease processes. The Clinical Management Coordinator functioned as the project team leader because she is the nursing supervisor at the site and was responsible for copying the asthma action plans for use in the clinic.

\section{Creating a Vision}

Kotter's third step is the development of a vision change, which is defined as determining what the vision change is within the organization and how the process change can merge with 
that vision (Kotter, 1995). Although the clinic did not have a vision statement, the purpose of this project was in line with the values and mission of the clinic. The documented values statement for the clinic is "WCHSA values integrity, compassion, and respect through the dedicated effort of every team member and has a goal to provide the highest quality of service to our patients, their families, and our communities" (WCHSA, 2013). The documented mission statement of WCHSA was "to improve the health status of communities we serve by providing access to patient centered quality health care" (WCHSA, 2013). In line with this vision, this project embraces the use of evidence-based practice, standard of care guidelines to promote delivery of high quality care to patients in Wirt County.

The organizational mission and goals required team members to work together in the best interest of the public. The project was feasible for the organization because the clinic was currently progressing toward patient centered medical home recognition. The organization recently added care managers for chronic disease management and updated the EMR with templates focused on federal funding measures. These changes increased the organization's ability to make the necessary process changes and incorporate asthma standards of care into practice.

\section{Communicating the Vision}

Kotter's fourth step in the model is communicating the vision, which is defined as using communication strategies and teaching new behaviors (Kotter, 1995). All staff involved in the process had to realize the buy-in related to the vision. This was accomplished by meeting with all clinic providers and nursing staff during a regular lunch staff meeting prior to the process change to review statistical data obtained from pre-program chart audits. Items discussed at this 
time included identifying what needs to be done as an organization to increase the usage of action plans and the process that will be utilized to increase implementation of the plans. Clerical staff involved in scanning information into medical records was educated separately on the process change during the same staff meeting.

During the educational meeting, team players were presented with the PACE program, an evidence based curriculum that has been tested and validated as an asthma education program for clinicians (NHLBI, 2013). At the beginning of the meeting, team players, excluding clerical staff, received the pretest (Appendix C) developed by the project director regarding materials included in the PACE training program to establish baseline knowledge on asthma management. Team players, excluding clerical staff, also received a binder with PACE educational materials, a copy of the slide presentation (Appendix D), peak flow meter educational materials (Appendix E), and an action plan for adults (Appendix F) and students (Appendix G) that will be used during the process change. The action plans for this process change were adapted from the American Lung Association of New Jersey (2013) and were in a paper format. The forms were chosen because of ease of use and were consistent with standard of care for patients with asthma. The action plans, adult and student, contain symptom based references and peak flow meter readings that direct the patient to initiate treatment. The action plans were presented to the team players with verbal instruction on how the nurse will initiate the form and the provider will implement the plan with the patient. A post test (Appendix C) was given to document change in knowledge after the educational session.

The educational in-service on the use of the action plan was based on the PACE curriculum. The team players, excluding clerical staff, were educated on how to fill out an 
asthma action plan. Due to time constraints the peak flow meter education session was omitted but participants were given the handout on how to perform peak flow meter testing. The same team players were given an opportunity to discuss the process for implementation of an action plan, obtaining peak flow meter readings, and how to instruct patients in the use of an asthma action plan. This allowed the team players to evaluate their skills and then discuss with other team players any needed changes in the process (Ockene \& Zapka, 2000).

The process of using the asthma action plans was as follows: (1) Copies of the action plan were provided by the clinical management coordinator to all team players at each patient room to increase utilization of the form; (2) The nursing staff then inquired, as they usually do during each visit encounter, if the patient has a current diagnosis of asthma; (3) Once clarified, the nurse clipped the blank action plan to the patient work chart; (4) Providers then addressed the action plan on every patient with asthma, barring emergent care issues, regardless of whether the visit was acute or routine in nature; (5) After the patient encounter, the provider clipped the completed plan on the patient work chart and returned it to the clerical staff for scanning and copying in the EMR; (6) The clerical staff then gave the patient the original action plan when the patient checked out at the end of the visit.

\section{Empowering Others to Act on the Vision}

The fifth step of Kotter's model is empowering others to act on the vision (Kotter, 1995). This step is defined as the removal of any barriers to the change process and encouraging nontraditional ideas (Kotter, 1995). Barriers to asthma management include lack of clinician knowledge of evidence-based guidelines, lack of convenience, and lack of comfort implementing asthma plan use and review (NAEPP, 2007). In this project, lack of provider knowledge was 
addressed by providing the team players, excluding clerical staff, with a PACE program binder containing those standards of care guidelines and an educational session on the PACE program. See Appendix D for full content of slides that were presented. Posters from the NAEPP were located in patient care rooms and in the team player's lunchroom to remind team players of the importance of asthma management (Appendix H). Placing asthma action plans on the work chart served to address lack of convenience in using the tool.

\section{Creating Short Term Wins}

The sixth step in Kotter's model is planning for and creating short-term wins. This is defined as planning for performance improvements and rewarding employees involved in the improvements (Kotter, 1995). During this step, it is important to have influence to encourage team players to follow through with the proposed changes (Kotter, 1995).

Specifically for this project, a follow-up education meeting was held to inform team players of process effectiveness. At that time, the staff were notified of the repeat chart audit showing how many action plans have been completed since the education meeting. The data collection tool used for the post education chart audit can be found in Appendix I. The audit results showed slight improvement in performance of using asthma action plans, a short term win. This improvement in performance can reinforce the need to continue with the change process once the capstone project is completed.

Another short term win for provider and nurse education could be the improvement in the knowledge post test scores. These types of results provide insight into possible barriers that may be encountered during delivery of care to patients with asthma related to knowledge.

\section{Consolidating Improvements and Producing Still More Change}


The seventh step of Kotter's model is to consolidate improvements and produce still more change (Kotter, 1995). This is defined as reinvigoration of the process by changing policies or staff that may not fit into the vision of the project (Kotter, 1995). At the end of process implementation, individual group discussion with team players and team leaders identified what worked or did not work. At the end of the pre and post chart audits, allowing team players to be included in the review of results promoted a sense of accomplishment and ownership of the change process.

\section{Institutionalizing New Approaches}

The final step of the model is institutionalizing the new process change which is defined as ensuring program succession and organizational success (Kotter, 1995). The team will have to examine measures to cement the changes within the organization. This will involve both leadership and staff members to brainstorm on ideas for project succession. The chart audits and staff input on the process were important to enable examination of what was successful and what they considered a hindrance to the process change.

\section{Literature Review and Synthesis}

The search strategy to identify the best evidence regarding action plans in reducing acute exacerbations of asthma included a detailed search of the National Guideline Clearinghouse, CINAHL, Pub Med, and the Cochrane Library. Keywords used for the search were asthma, acute care visits, and self-management. The initial search yielded 1,867 hits. The search was narrowed to include the term action plans and peak flow meter, which yielded 52 hits. Only studies from 2001 to present, English language, clinical practice guidelines, randomized controlled trials, systematic reviews, and peer-reviewed journal articles were included. One 
clinical practice guideline offered recommendations for providers of health care to implement asthma action plans to improve patient outcomes (NAAEP, 2007). Seven other studies met the criteria for inclusion as well. Two systematic reviews (Zemek et al., 2008; Wolf et al., 2002), four randomized control trials (Bartholomew et al., 2006; Sockrider et al., 2006; Burkhart et al., 2007; Huang \& Wang, 2009), and one cohort study (Camargo, Reed, Ginde, Clark, Emond, \& Radeos, 2008).

The search strategy to identify the best evidence regarding education of providers and nursing staff on evidenced based guidelines related to asthma included a detailed search of the National Guideline Clearinghouse, CINAHL, Pub Med, and the Cochrane Library. Keywords used for the search were asthma, educating providers, and clinical guidelines. The initial search yielded 4,406 hits. The search was narrowed to include the term provider education and provider prompting, which yielded 15 hits. Only studies from 2003 to present, English language, clinical practice guidelines, randomized controlled trials, systematic reviews, and peer-reviewed journal articles were included. Four RCTs studies met the criteria for inclusion (Brown, Bratton, Cabana, Kaciroti, \& Clark, 2004; Feldstein, Elmer, Smith, Herson, Orwoll, Chen, Aickin, \& Swain, 2006; Halterman, Fisher, Conn, Fagnano, Lynch, Marky, \& Szilagyi, 2006; Sullivan, Lee, Blough, Finkelstein, Lozano, Inui, Fuhlbrigge, Carey, Wagner, \& Weiss, 2005).

\section{Critical Appraisal}

A critical appraisal was conducted on each of the documents using the appropriate tool. The clinical practice guideline was appraised using the AGREE II form (AGREE, 2009). The eight randomized control trials (RCTs) were individually appraised for the overall assessment, 
internal validity and description of the study (Scottish Intercollegiate Guideline Network [SIGN], 2009).

The clinical practice guideline (NAEEP, 2007) provided recommendations for improving asthma outcomes. Those recommendations, at level A for evidence, promote asthma selfmanagement education for patients and are a standard of care in asthma (NAEEP, 2007). According to the NAEEP (2007), action plans must include both the daily management of asthma and instruction on how to determine if symptoms are deteriorating and when to seek medical care. The guideline also recommends action plans based on asthma severity and need for self-management education by a health care clinician, involvement by all health care team members, and occur at all points of care including clinics (Evidence B) (NAEEP, 2007).

The data collection methods were clearly outlined, the population was clearly defined and the views of relevant health care professionals were included in the guideline. The guideline development included peer review and expert panel review. The guideline was reviewed and approved by several organizations including the Agency for Healthcare Quality, the American Academy of Allergy, Asthma, and Immunology, the American Lung Association, the American Medical Association, the American Nurses Association, and the American Academy of Pediatrics.

The two systematic reviews demonstrated limited support of the benefits of using action plans. One systematic review (Zemek et al., 2008) found limited data to reach a conclusion that the implementation of an action plan has any effect on reducing acute care visits. The other systematic review (Wolf et al., 2002) found that self-management interventions, such as action plans, demonstrated a modest decrease in acute care service utilization. In both systematic 
reviews, findings were conflicting related to which action plan is more effective, symptombased action plans (Zmeck et al., 2008) or peak flow based action plans (Wolf et al., 2002). The systematic reviews were assessed for internal validity. One of the systematic reviews had an identified purpose (Wolf et al., 2002) and one had a clearly stated question (Zemek et al., 2008). A description of the methodology was included in both reviews and clearly defined. The systematic reviews conducted a rigorous literature search to identify all relevant studies. Zemeck et al. found only RCTs or quasi-randomized controlled trials were allowed. Wolf et al. found only RCTs or clinical controlled trials were included.

The limitations to Zemeck et al. (2008) were that only one published RCT affected ability to make firm conclusion regarding use of action plan or not in care, no concrete support of action plan use in children as being effective in asthma management, the review had a small number of trials which may have affected secondary outcomes, and the compliance of using action plans was not monitored. In Wolf et al. (2002), patients receiving self-management education had limited improvements in outcomes related to acute care encounters in the emergency department, patients with more severe asthma benefited from education more than those with a mild form of asthma, and peak flow based action plans were better than symptom based action plans in relationship to performance and outcomes. Zmeck et al. reviewed 428 citations and used five RCTs in their systematic review. Wolf et alreviewed 318 citations and used 32 RCTs in their systematic review.

One RCT (Burkhart et al., 2007) found that use of action plans were beneficial in reduction of acute care encounters ( $\mathrm{p}>0.01)$. In another RCT (Bartholomew et al., 2006), the evidence demonstrates that there is no significant difference in the number of acute care visits for 
asthma exacerbation after the asthma action plan was implemented $(p=0.053, p=0.0016$ respectively). In Sockrider et al. (2006), those participants classified as having mild intermittent asthma did result in a significantly lower number of acute care visits compared to those participants in the control group at $95 \% \mathrm{CI}(0.12-0.88)$. Three of the RCTs had control and intervention groups with the intervention being the asthma diary (Burkhart et al., 2007), and action plans (Bartholomew et al., 2006; Sockrider et al., 2006). One RCT (Huang \& Wang, 2009), randomly assigned patients into groups of usual care, individualized education, and individualized education with peak flow monitoring. The cohort study (Camargo et al., 2008) found a low prevalence of action plan use in patients presenting at the emergency department. In the four RCTs related to provider or nursing education, patients were randomly assigned between control or intervention groups (Brown et al., 2004; Feldstein et al., 2006; Halterman et al., 2006; Sullivan et al., 2005).

While self-management education is noted in the evidence based practice guidelines as a key clinical activity and health professionals should address guidelines when treating patients, the inconsistent evidence does not support this recommendation (NAEEP, 2007). In four of the RCTs, education on self-management was included in the studies and related to the use of action plans or asthma diaries (Bartholomew et al., 2006; Burkhart et al., 2007; Sockrider et al., 2006). One RCT by Burkhart et al. demonstrated a reduction in acute care visits after 8 weeks of intervention. Bartholomew et al. found that education received by participants demonstrated an increase in hospitalizations $(\mathrm{p}<0.001)$ but no difference between intervention groups by posttest. Sockrider et al. educational interventions involving action plans did not have a significant impact on acute care encounters. Huang and Wang (2009) participants in the education with peak flow 
meter intervention group had statistically significant asthma control when compared to the other group without peak flow meter $(\mathrm{P}<0.05)$.

In the four RCTs related to provider education, patient outcomes improved when providers or nurses were given evidence based education (Brown et al., 2006, Feldstein et al., 2006; Sullivan et al., 2005) or physician prompting (Halterman, et al., 2006). Brown et al. demonstrated a reduction in emergency room admissions over the two-year study period when compared to the usual care group. Feldstein et al. found that clinical guideline prompting through the electronic medical record and provider education related to patient specific treatment guidelines resulted in statistically significant improvements in patients receiving evidenced based care at $43.1 \%$ in intervention group versus $5.9 \%(\mathrm{P}<0.001)$ in usual care group respectively. Providers were given EMR prompts in the form of a letter that had specific patient information available for provider review (Feldstein et al., 2006). It is noted that patient education and provider prompt patient advice did not have a significant impact on outcomes when compared to advice alone $(\mathrm{P}=.88)$ (Feldstein et al., 2006). It was hypothesized that a patient reminder including EMR reminder may increase patients' knowledge of treatment options, but a single letter did not provide a significant increase in those receiving the specific treatment (Feldstein et al., 2006). In Halterman et al. non electronic medical record provider prompts involving patient care guidelines resulted in an increase in preventative measures versus usual care at $87 \%$ and $69 \%$ respectively. In Sullivan et al. team leaders were educated at each participating site and an asthma nurse provided self-management education or usual care to participants. The study reported that symptom free days were improved in the intervention group by an increase of 13.3 
days (95\% CI, 2.1-24.7) but organizational costs were also increased versus usual care (Sullivan et al., 2005).

The eight RCTs and one cohort study were assessed for internal validity. All five of the studies had an identified purpose or objective but none was addressed in a PICOT question format. All of the studies analyzed the subjects in the groups in which they were assigned. All eight of the RCTs had reliable instruments to evaluate their outcomes and each study addressed a different outcome. All eight of the RCTs had a random assignment of subjects to the intervention groups, but the method was not reported in two of the studies (Bartholomew et al., 2006 \& Sockrider et al., 2006). In Camargo et al. (2008) patients were randomized by age and diagnosis. Two of the RCTs, quasi-experimental and cohort studies had blinding of the subjects or the investigators (Feldstein et al., 2006; Huang \& Wang, 2009).

The eight RCTs and one cohort study were evaluated in regards to the threats to internal validity. The loss of participants, short length of study, and small sample size was noted in one RCT (Burkhart et al., 2007). In two other RCTs (Bartholomew et al., 2006 \& Sockrider et al., 2006), the sample size was small but the length of the studies were 3 years and 9 months respectively, but there was concern about follow up because of high turnover rate of participants. In one RCT (Huang \& Wang, 2009), the study involved patient education over a six month period at only one medical center which may have led to confounding factors. In Sockrider et al. (2006), validity of information related to chart reviews was noted due to inability to obtain records from non-participating hospitals. Although there were some threats to internal validity, all four of the RCTs used instruments that have been proven reliable and the outcomes identified were measureable. Camargo et al. (2008) reported confounding due to issue related to having an 
action plan and not implying a causal relationship between plan and acute care visits. Feldstein et al. (2006), in a study related to provider education impacting patient's obtaining bone mineral density testing, reported that patients with more disease processes and higher age were not as likely to obtain the desired intervention of bone mineral density testing as their younger counterparts. Halterman et al. (2006) reported that bias may have been present in the selfreporting phase of the patient survey and some patients may have failed to prompt their physicians as directed. The findings were also obtained at smaller practice sites and therefore may only be generalized to practices with similar attributes (Halterman et al., 2006). In Brown et al. (2004), race of children in the study and parental education levels may have caused a bias in the results. Although there were some threats to internal validity, strengths of all nine of the studies included instruments proven reliable and outcomes identified and measureable.

\section{Synthesis}

The Expert Panel on Asthma Guidelines (NAEPP, 2007) provides strong recommendations for the use of asthma action plans to improve asthma related health outcomes and provider education on asthma action plan implementation. One systematic review (Zemek et al., 2008) found that symptom based action plans are shown to be as effective as or more effective than symptom based plans. In Wolfe et al. (2002), peak flow based action plans were superior to symptom based action plans. In three studies, the use of action plans or patient selfmanagement education not specified as symptom or peak flow based, improved patient outcomes with a reduction in acute care visits (Bartholomew et al., 2006; Burkhart et al., 2007; Huang \& Wang, 2009). In four studies, provider education or physician prompting improved patient outcomes (Brown et al., 2006; Feldstein et al., 2006; Sullivan et al., 2005; Halterman et al., 
2006). There are gaps in the knowledge base that are specific to whether patients who report they have action plans are actually using them correctly (Burkhart et al. (2007). Further studies based on adults with asthma and provider education impact on implementation of action plans are needed in the future.

\section{Project Objectives}

The original PACE program is five hours long with two didactic courses covering the asthma standards of care and communication. For this clinic to meet administrative limits, the course was compressed to one hour. The specific objectives for this capstone project were: (1) Providers and nursing staff will attend one educational session regarding the use of action plans and will learn about asthma management (plan); (2) The healthcare team will implement asthma action plans based on the process change (do); (3) Chart audits data and pre/post knowledge testing scores will be reviewed to identify degree of change in practice (evaluation).

\section{Project Design}

After IRB approval, the program was conducted over 1 year. To meet project objectives the project manager did the following. To meet objective 1 an educational session was presented to clinic personnel. During this education session current standards of care and the process change were reviewed. A knowledge test was completed before and after the educational session. To meet objective 2 packets containing the asthma action plan were provided to clinic personnel. Each action within the process was reviewed with stakeholder to enable follow through. To meet objective 3 , the project leader reviewed data obtained from pre and post chart audits and the knowledge test to assess the effectiveness of the process change.

\section{Population Targets}


The population target for the educational intervention to improve asthma control were the primary care providers and nursing staff at a rural federally qualified healthcare clinic located in western West Virginia. The health center has two MDs, two Pas, one FNP, three LPNs, one RN, and one MA. One of the medical doctors also functions as the medical director. In the context of this project, the primary care providers, nursing staff, and clerical staff involved in scanning patient records are referred to as team players. The population target for the chart reviews included pediatric and adult patients diagnosed with asthma.

\section{Resources}

Resources for this project were identified during the project preparation stage. Materials to implement the PACE program, obtained free of charge on the NHLBI website, included education binder material and the program facilitator instructional material. Free posters to hang in work areas and educational materials for the providers and nurses were obtained from the Director of the West Virginia Asthma Education Prevention Program. The adult and pediatric asthma action plans were obtained free of charge from the American Lung Association of New Jersey website. The paper to print the asthma action plans, copier use, scanner use, space for educational intervention, lunch for staff, and employee time was donated by the clinic. Overall, the final cost for the project was minimal. See Appendix J for the project budget.

\section{Project Timeline}

This project occurred in three phases. The first phase of the project involved project planning, including submission to the WVU IRB. Once the protocol was approved, baseline data collection occurred. The implementation phase spanned a six week process and included the training of team players and implementation of the process change. The final phase, evaluation, 
involved completion of data collection and data analysis. SMART objectives for the project manager to carry out the project and the project timeline are located in Appendices $\mathrm{K}$ and $\mathrm{L}$ respectively

\section{Evaluation}

The first objective was to provide education to clinic personnel to improve their knowledge of asthma self-management, to increase utilization of action plans, and to foster education of patients. The providers and nursing staff, excluding clerical staff, completed a pre and posttest on asthma management to determine their knowledge level.

The second objective was to implement the process change. Periodic assessment of forms was conducted by the program manager to confirm the process was taking place in the clinic. The number of patients receiving an asthma action plan during a routine or acute care visit was assessed through pre and post chart audits via Pearson Chi Square statistical analysis.

The third objective was to evaluate the effectiveness of the process change. In addition to the use of asthma action plans, the frequency of documentation of individual variables associated with asthma action plans were also reviewed in provider's notes. The post process change audit form can be located in Appendix I. The pre and post test of the PACE program is located in appendix C.

\section{Results}

\section{Pre and Post Knowledge Testing}

The problem addressed in this project was providers and nurses at the Wirt County clinic were not documenting the use of asthma action plans in the care of patients with asthma, which was a failure to follow standards of care in asthma management. The project manager conducted 
asthma action plan training, assessed clinic personnel knowledge, monitored use of the asthma action plans, and evaluated efficacy of the process change through chart audits and assessment of variables in provider's patient care notes. There were 23 staff members that were available for

the educational session with 7 nurses, 5 providers, and 11 clerical staff participating. Eight staff members completed both the pre and post tests and returned the forms for processing. The session was completed with discussion of process change and post test completion. The table in Appendix M table summarizes knowledge test results.

Question one was answered correctly 8 times (100\%) pre education and 7 times $(87.5 \%)$ post education. Questions two and three participants were answered correctly by all participants both times. Question four was omitted from the calculation due to poor wording. Question five, participants correctly identified 4 benchmarks (20\%) of good asthma control compared to 10 benchmarks (50\%) following the education session.

\section{Asthma Action Plan Chart Audit}

The asthma action plan completion rate demonstrated a minimal increase in use of the action plan from the pre chart audit through the post chart audit. There were 50 charts audited before the educational session and 50 following the educational sessions. The average age of patients whose charts were audited pre educational intervention was $35(\mathrm{SD}=22.3589)$ while post educational intervention chart audits was $38.9(\mathrm{SD}=19.3660)$. The pre educational chart audit did not locate any asthma action plans on the patient charts $(0 \%)$; while the post educational chart audit identified two charts containing asthma action plans (4\%). The Pearson Chi-Square test compared the use of action plans pre and post provider education. There was no significant 
association between provider education and completion of the asthma action plans, $\mathrm{X}^{2}(1$, $\mathrm{n}=100)=2.04, p=0.153$.

Asthma action plans were not only reviewed to assess the process change. The documentation of the five variables specific to the asthma action plan (peak flow or symptom severity, medications (frequency and dosage), documentation of triggers, patient education; plan adjustment), were also assessed during the chart audits to determine if variables were present on patient records separate from an asthma action plan. The Pearson Chi-Square test was again conducted to determine an association between provider education and documentation. There was no significant change in peak flow meter documentation between pre and post chart audits, $\mathrm{X}^{2}(1, \mathrm{n}=100)=3.84, p=0.05$. The medication variable could not be measured due to insufficient data. The number of charts documenting triggers was seven (14\%) on pre audit and eleven $(22 \%)$ on post audit, but no significant association existed, $\mathrm{X}^{2}(1, \mathrm{n}=100)=1.08, p=0.30$.

Symptom documentation showed no change as well, $\mathrm{X}^{2}(1, \mathrm{n}=100)=0.15, p=0.70$. No significant association for the education variable was found, $\mathrm{X}^{2}(1, \mathrm{n}=100)=0.80, p=0.37$ nor was there a significant association found related to the plan adjustment variable, $X^{2}(1, n=100)=0.33$, $p=0.56$.

\section{Discussion and Recommendations}

The framework for the project was John Kotter's 8-step process for leading change. The decision to proceed with the project was a joint effort between management personnel and providers. The coalition was formed, vision created, vision communicated, others empowered to act on the vision, plans for short term wins, and plans for the future. Although no changes occurred in the use of asthma action plans, an unintended consequence was a perceived increase 
in the number of referrals to the project leader for asthma education. Participating providers also commented that the asthma education program binder contents assisted them in treatment decisions related to asthma care.

Many barriers existed in implementing this project. Barriers to the educational intervention included difficulty in scheduling the meeting time to coordinate with staff schedules and difficulty conducting the education due to a mixed group of clerical and clinical staff. Staff buy in from management was high, but buy in from other staff was more difficult. The project was accepted by staff and participation was high for the education session because it was conducted during a routine staff meeting time slot. Staff commented that having a binder with information related to guidelines was important and would help them improve action plan use. One factor that may have impacted the minimal increase in documentation of variables was the recent change in providers at the clinic.

There were also problems in obtaining enough patient charts for the audit. The information technology (IT) contact person was not readily available during the pre chart audit so obtaining lists of patients with a diagnosis of asthma was difficult. The contact person changed before the intervention was conducted so there was more ease in finding patients during the post audit. Another reason for increased ease was having more patients with a diagnosis of asthma listed in the problem list after the education session. It is unknown if the education session affected the problem list.

\section{Recommendations}

In the future, this type of project could be utilized at the school based health centers in the area. Currently, the school is working with the wellness center to increase the use of peak flow 
meters and asthma education with students. This project could allow the provider and school nurse to collaborate on patient care and get the action plans filled out. I feel that the project was not as successful at the main clinic site because of the range of patient ages and provider commitment was not strong. Recommendations have been made at provider meetings related to providing education to the providers on standards of care of various chronic disease processes. This education session was offered to one site but in the future the education or binder information could be forwarded to other offices within a larger organization. There are no current plans for this process to happen but the resources are available when the decision is made.

The organizations' strategic plan involves expanding services to patients to promote healthy lifestyles. This plan can include the process change as outlined in this capstone project. Similar projects related to other disease processes could also be examined and implemented with adequate buy in from the management, clinical staff, and community members. Careful attention must be made to ensure adequate representation of the population is present in the catchment area to satisfy sampling requirements before any program is implemented. In the future, this organization plans to expand services and continue to improve patient care outcomes.

\section{Personal Leadership}

This project contributed to the attainment of my personal leadership goals through increasing my knowledge of asthma care, providing encouragement related to presenting information to a large group, and evaluating budget plans and the process of organizing a large project. I am now familiar with the steps to make a process change and I can apply those steps to other projects that I may become involved with at my organization. I have also had the 
opportunity to network with my colleagues, fellow students, faculty, and community to move towards becoming a clinical expert in my field. I am looking forward to the future and have plans to incorporate the knowledge that I have into my current and future practice. I look forward to continuing to expand services that are offered at my organizational site. 


\section{Appendix A}

\begin{tabular}{|c|c|}
\hline Kotter's Change theory & Steps for Change \\
\hline 1. Establishing a sense of urgency & $\begin{array}{l}\text { Identify and discuss why action plans should } \\
\text { be implemented in the organization. }\end{array}$ \\
\hline 2. Forming a powerful guiding coalition & $\begin{array}{l}\text { Assemble coalition as a group with enough } \\
\text { power to lead change. } \\
\text { Obtain approval of CEO, MDS, RN } \\
\text { Identify stakeholder }\end{array}$ \\
\hline 3. Creating a vision & $\begin{array}{l}\text { Create a vision and develop strategies to obtain } \\
\text { the vision. } \\
\text { Determine organizations mission statement. } \\
\text { Compare project vision and organization's } \\
\text { mission statement. }\end{array}$ \\
\hline 4. Communicating the vision & $\begin{array}{l}\text { Educate providers, nurses, and clerical staff on } \\
\text { process change using PACE program. }\end{array}$ \\
\hline 5. Empowering others to act on the vision & $\begin{array}{l}\text { Remove obstacles for team and change system } \\
\text { for action plan completion. } \\
\text { Provide providers and nurses with a binder of } \\
\text { standard of care guideline and reference tools. }\end{array}$ \\
\hline $\begin{array}{l}\text { 6. Planning for and creating short-term } \\
\text { wins }\end{array}$ & $\begin{array}{l}\text { Chart audit results } \\
\text { Post test scores from PACE program }\end{array}$ \\
\hline $\begin{array}{l}\text { 7. Consolidating improvements and } \\
\text { producing still more change }\end{array}$ & $\begin{array}{l}\text { Provide team players and team leaders a time } \\
\text { for discussion of what worked and what did } \\
\text { not work in the program. }\end{array}$ \\
\hline 8. Institutionalizing new approaches & $\begin{array}{l}\text { Present outcomes for process change to the } \\
\text { stakeholders to ensure succession of the } \\
\text { process change. } \\
\text { Discuss chart audit findings. } \\
\text { Make policy changes if program is successful. }\end{array}$ \\
\hline
\end{tabular}


Appendix B

\section{Pre-Chart Review}

\begin{tabular}{|c|c|c|c|c|c|}
\hline $\begin{array}{c}\text { Patient Chart } \\
\text { Code ID Number }\end{array}$ & Age & $\begin{array}{c}\text { Diagnosis Codes Used } \\
\text { During Encounter }\end{array}$ & $\begin{array}{l}\text { Diagnosis Codes } \\
\text { Omitted During } \\
\text { Visit }\end{array}$ & $\begin{array}{c}\text { *Action Plan in Chart Last } 6 \\
\text { Months } \\
\text { Y (Yes) or N (No) }\end{array}$ & $\begin{array}{c}\text { Provider/Nurse } \\
\text { Code Letter }\end{array}$ \\
\hline & & & & & \\
\hline & & & & & \\
\hline & & & & & \\
\hline & & & & & \\
\hline & & & & & \\
\hline & & & & & \\
\hline & & & & & \\
\hline & & & & & \\
\hline
\end{tabular}

*ID variables in the provider note: Peak flow; symptom severity, medications (frequency and dosage), documentation of triggers, patient education; plan adjustment. The asthma diagnosis codes and asthma related diagnosis codes are included on next sheet. 


\begin{tabular}{|c|c|}
\hline Asthma/Related Diagnosis & ICD9 Code \\
\hline 493.82 & Asthma Cough Variant \\
\hline 493.92 & Asthma Unspecified with Acute Exacerbation \\
\hline 493.91 & Asthma with Status Asthmaticus \\
\hline 493.90 & Asthma without Status Asthmaticus \\
\hline 493.21 & $\begin{array}{l}\text { Chronic Obstructive Asthma with Status } \\
\text { Asthmaticus }\end{array}$ \\
\hline 493.22 & $\begin{array}{l}\text { Chronic Obstructive Asthma With Acute } \\
\text { Exacerbation }\end{array}$ \\
\hline 493.81 & Exercise Induced Asthma \\
\hline 493.01 & Extrinsic Asthma with Status Asthmaticus \\
\hline 493.02 & $\begin{array}{l}\text { Extrinsic Asthma without Status } \\
\text { Asthmaticus }\end{array}$ \\
\hline V17.5 & Family History of Asthma \\
\hline 493.11 & Intrinsic Asthma with Status Asthmaticus \\
\hline 493.10 & Intrinsic Asthma without Status Asthmaticus \\
\hline 493.12 & Intrinsic Asthma with Acute Exacerbation \\
\hline 466.0 & Bronchitis \\
\hline 465.9 & Upper Respiratory Infection \\
\hline 786.2 & Chronic Cough \\
\hline 492.0 & Emphysema \\
\hline 477.9 & Allergic Rhinitis \\
\hline 491.0 & Simple Chronic Bronchitis \\
\hline 491.0 & Mucopurulent Chronic Bronchitis \\
\hline 491.21 & $\begin{array}{l}\text { Obstructive Chronic Bronchitis with Acute } \\
\text { Exacerbation }\end{array}$ \\
\hline 491.22 & $\begin{array}{l}\text { Obstructive Chronic Bronchitis without } \\
\text { Acute Exacerbation }\end{array}$ \\
\hline 491.8 & Chronic Bronchitis NEC \\
\hline 491.9 & Chronic Bronchitis NOS \\
\hline
\end{tabular}




\section{Appendix C}

\section{Pre/Post Education Test}

1. Appropriate asthma management requires the proper use of
A. Long term control
B. Quick relief medication
C. Asthma action plans
D. All of the above

2. Provider should review the asthma action plan
A. Every 3 months
B. Every 6 months
C. Every year
D. At each visit updating as needed.

3. Asthma action plans should only include medication names but no doses.
A. True
B. False

4. All patients should have an initial severity assessment based on
A. Measures of current impairment
B. Future risk
C. None of the above
D. All of the above

5. Name 2 benchmarks of good asthma control
A.
B. 


\section{Appendix D}
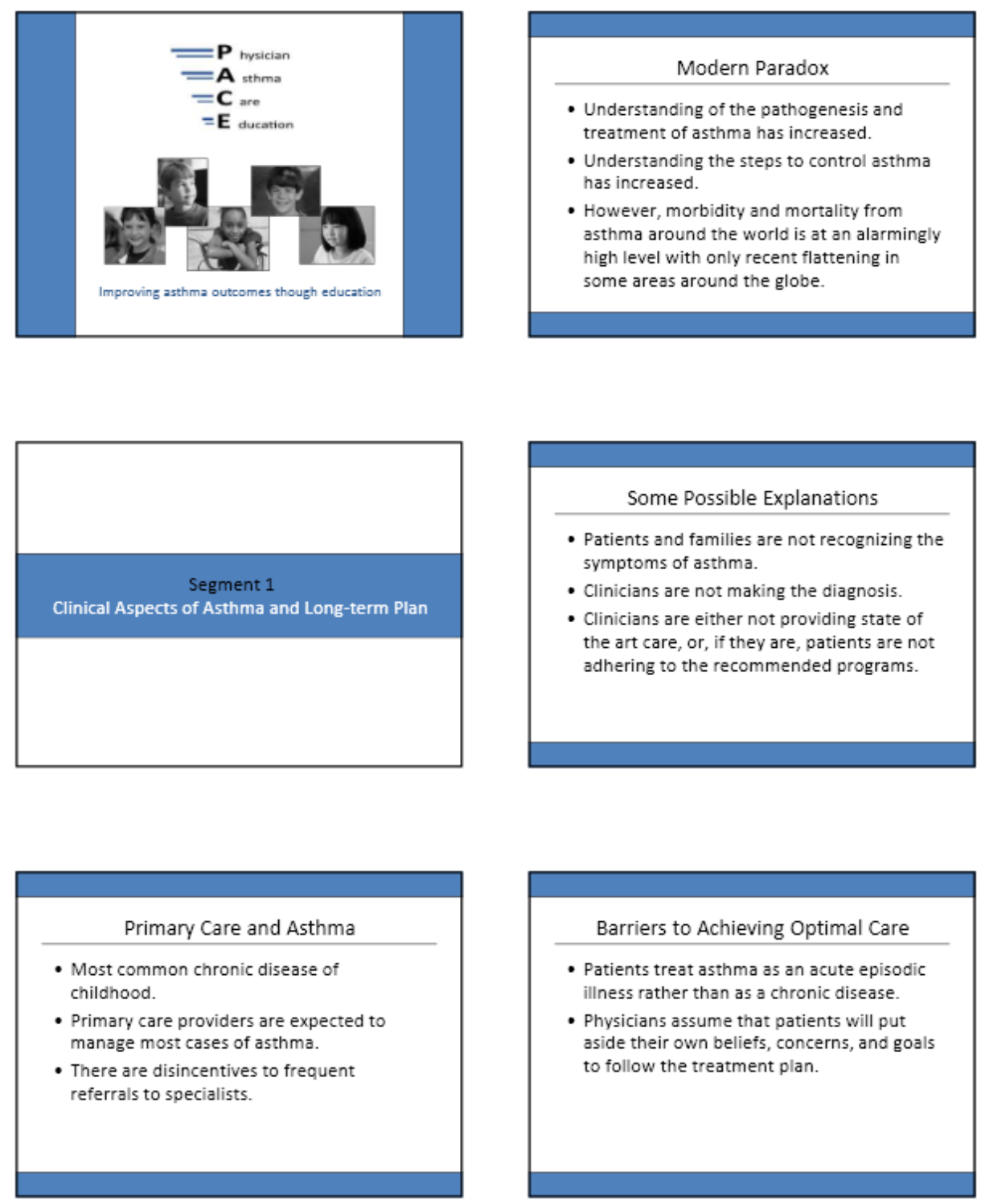

PACE Slides: Session 2, Segment 3 


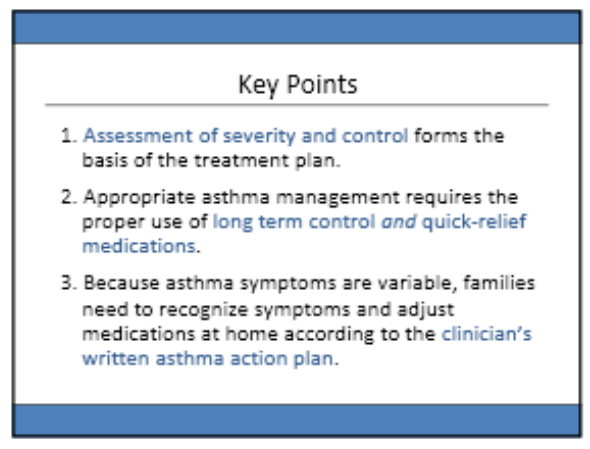

\section{Key Points}

4. Good communication between patient and clinician helps identify patient concerns, makes patient teaching more effective and promotes patient selfconfidence to follow the treatment plan.

5. Initial patient education can be efficiently and effectively accomplished in several standard primary care visits.

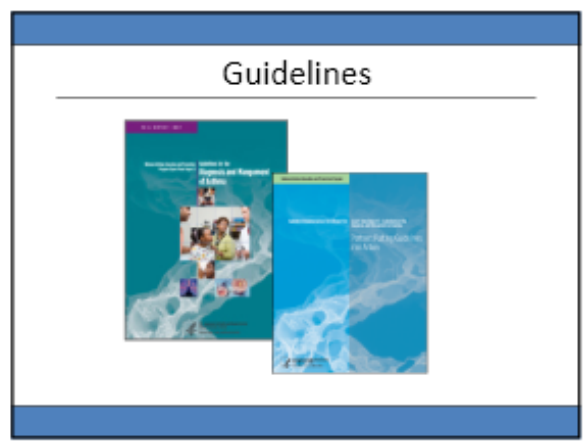

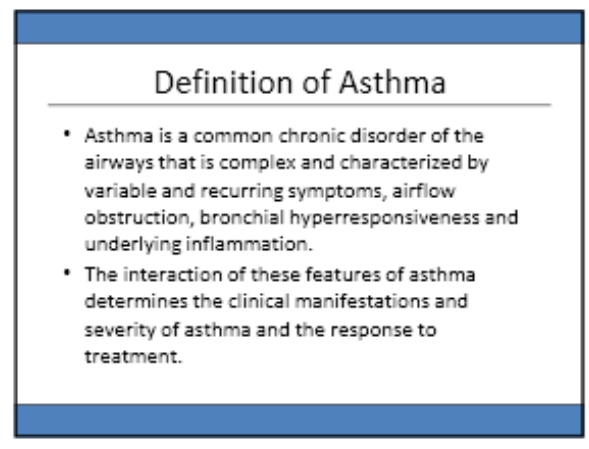
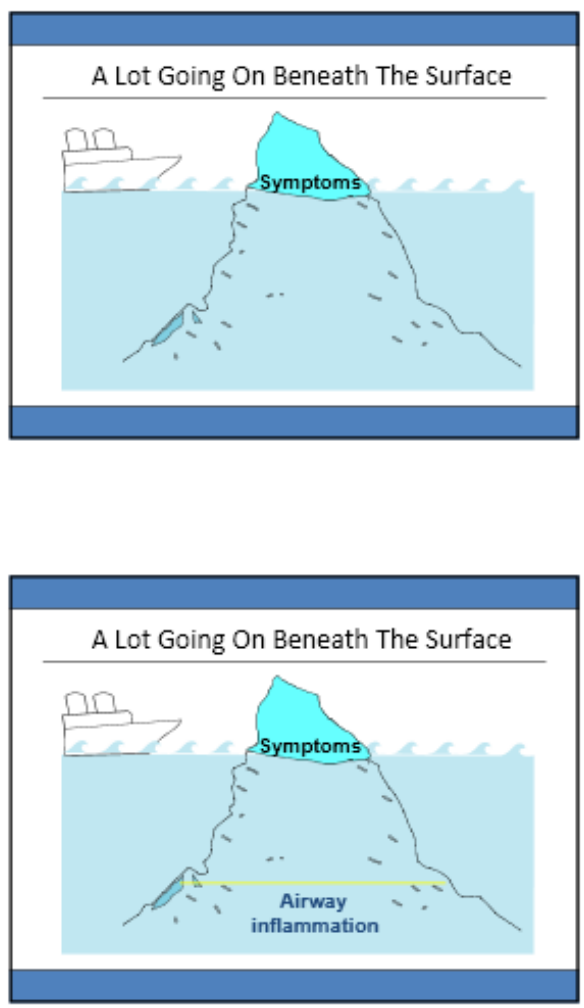

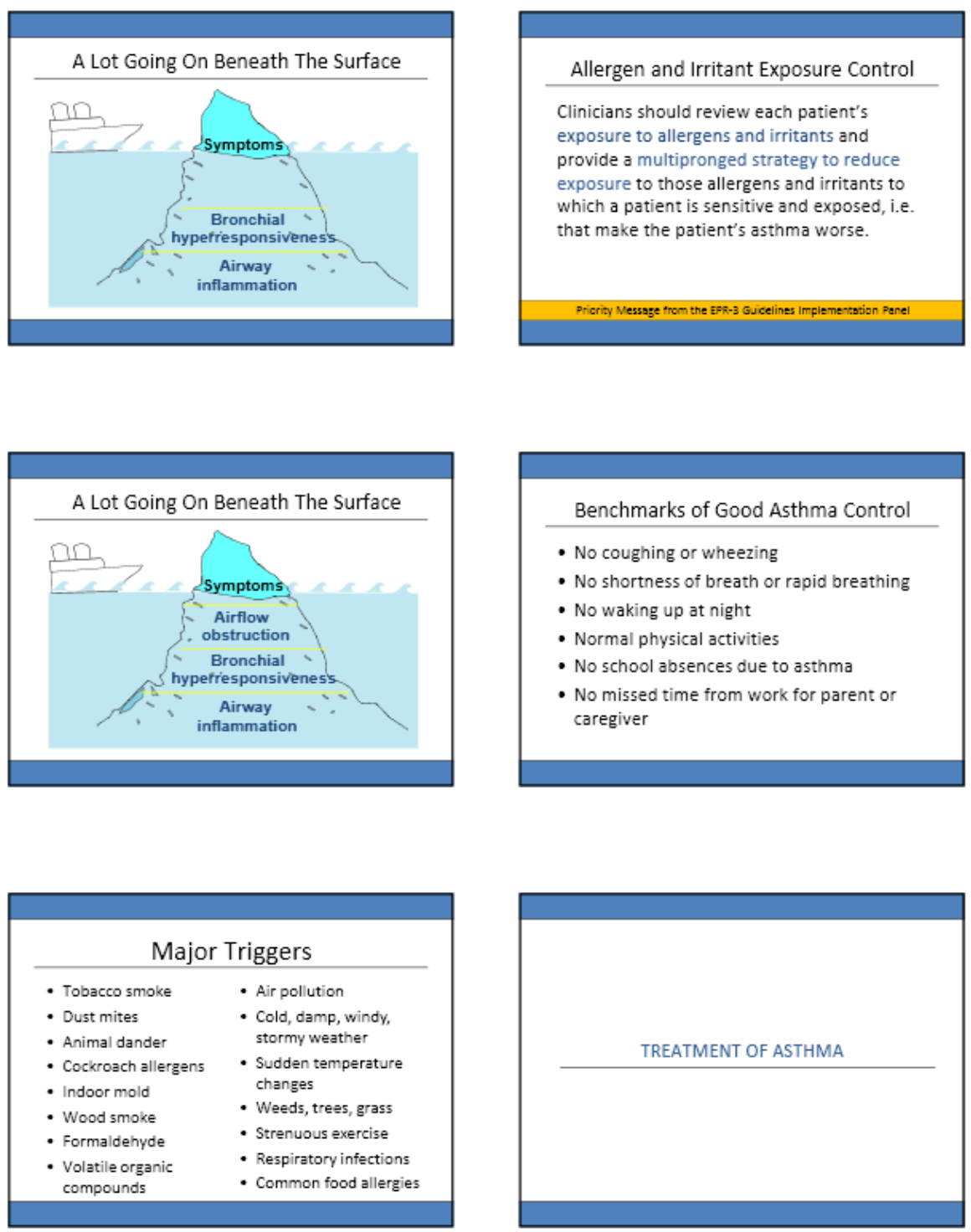

PACE Slides: Session 2, Segment 3 

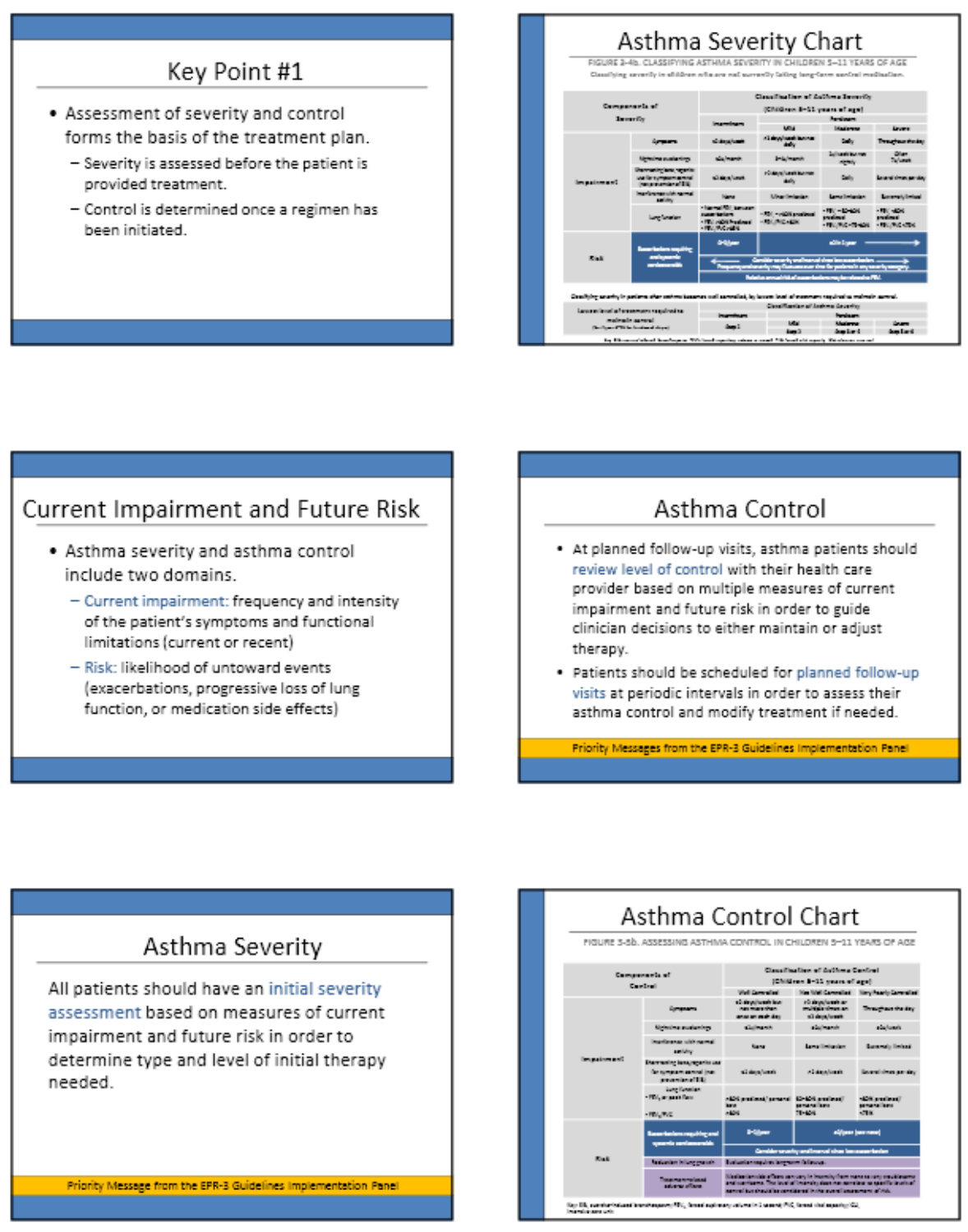

PACE Slides: Session 2, Segment 3 


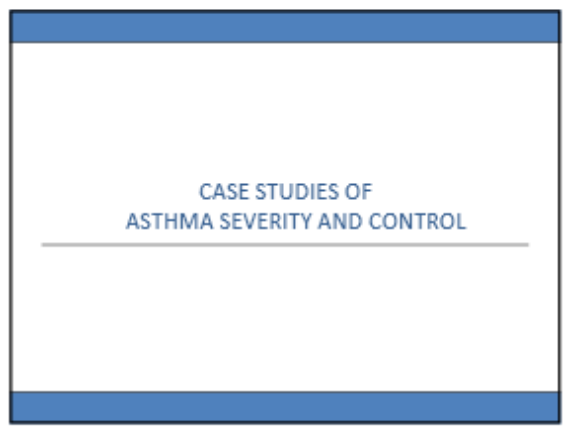

\section{Case Study 2}

Your 17 year old female patient has just returned home from her first year in college. She is compliant with her long term control medicriton and denies nignttime symptoms. She notes

forgets her medication prior to workouts. She is using

albuterol for exercise pre-treatment about 3-4 times a week,

but not requiring rescue medication. She has not nesded

recent urgent care or prednisone therapy.

- What is her level of control?

Case Study 1

You meet a 3-year-old boy with a long history of recurrent coughing who was recently seen in the urgent care due to a severe cough. He was given oral steroids for 3 days and is improving, according to his mother. The child is happy and plathlin the room with you. His history is remarkable for menths of ase for room visits between 6 months and 18 questioning the mother notes the child haster. Neter further questioning, the mother notes the
she gives him albuterol aften.

- What is your diagnosis?

-What level of severity does this patient have?
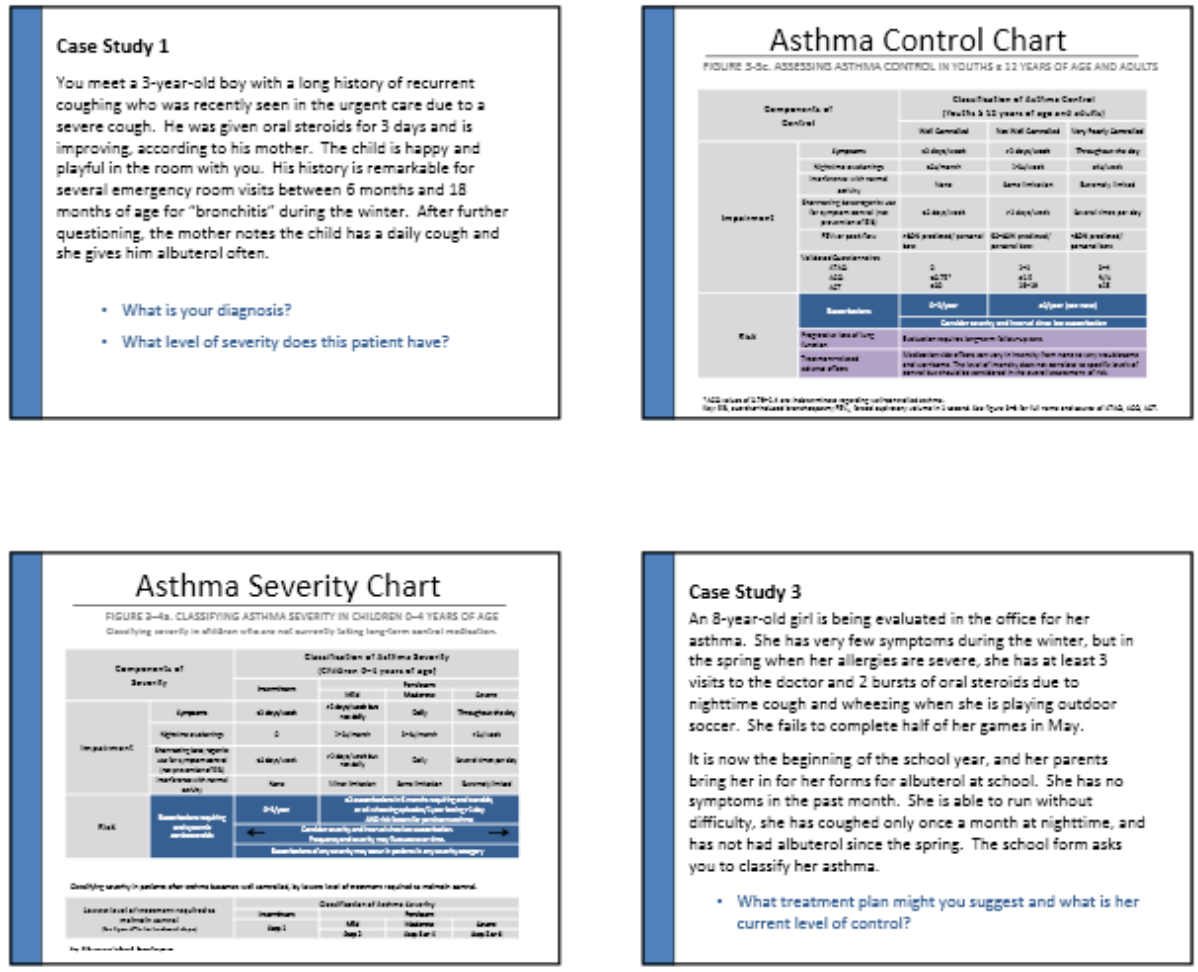

Case Study 3

An B-year-ald girl is being evaluated in the affice for her asthma. She has very few symptoms during the winter, but in the spring when her allergies are severe, she has at least 3 visits to the doctor and 2 bursts of oral steroids due to nighttime cough and wheezing when she is playing outdos. soccer. She fails to complete half of her games in May. It is now the beginning of the school year, and her parents bring her in for her forms for albuterol at school. She has no symptoms in the past month. She is able to run withou difficulty, she has coughed only once a month at nighttime, and has not had albuterol since the spring. The school form asks you to classify her asthma.

- What treatment plan might you subgest and what is her current level of control? 

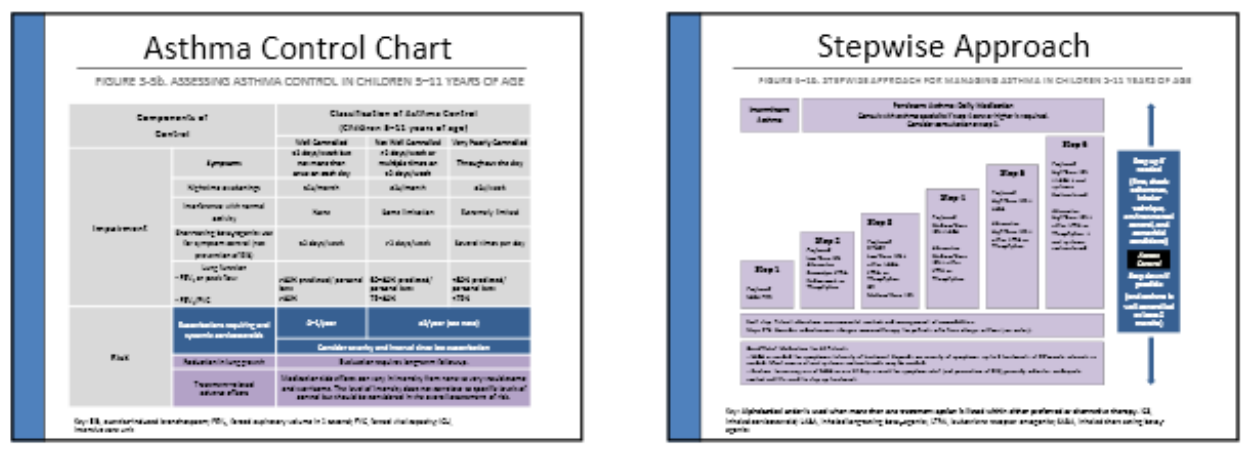

\section{Key Point \#2}

- Appropriate asthma management requires the proper use of long term control and quick-relief medications.

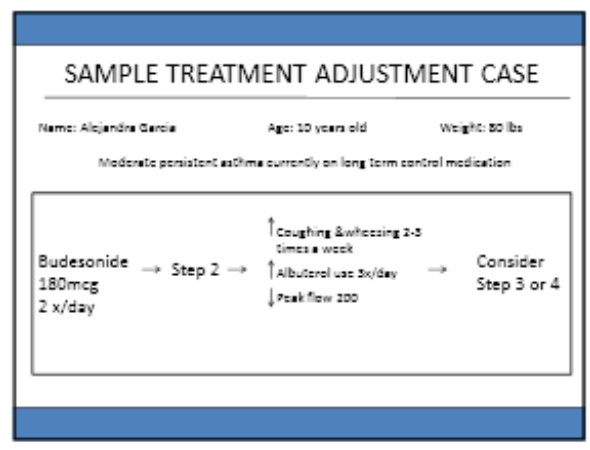

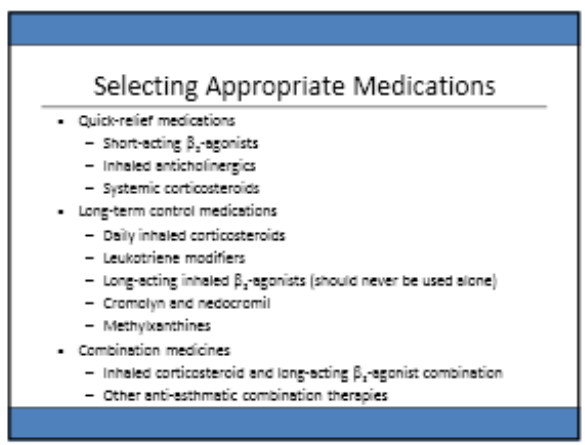

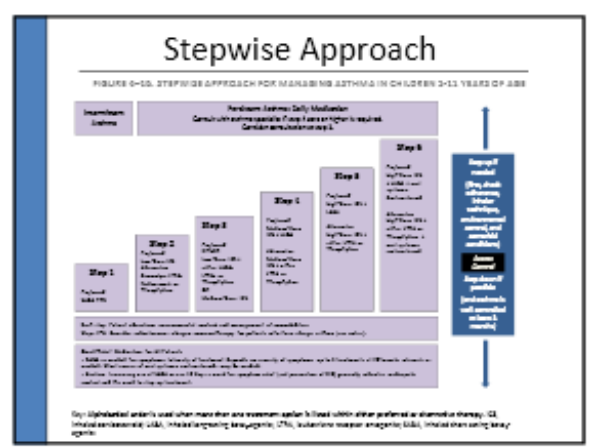

PACE Slides: Session 2, Segment 3 

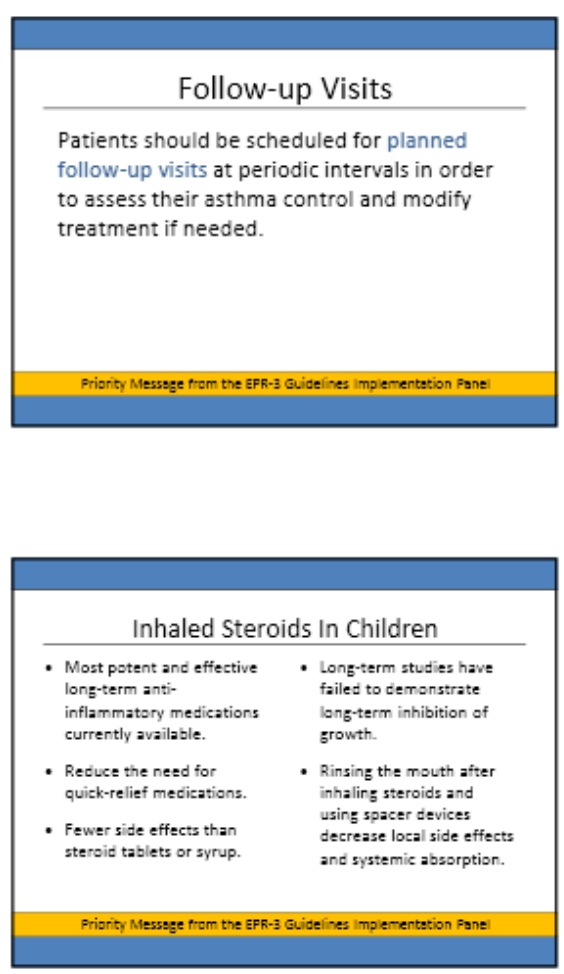

Key Point \#3

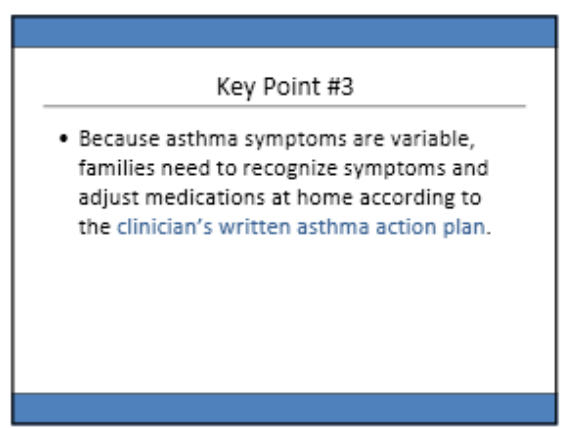

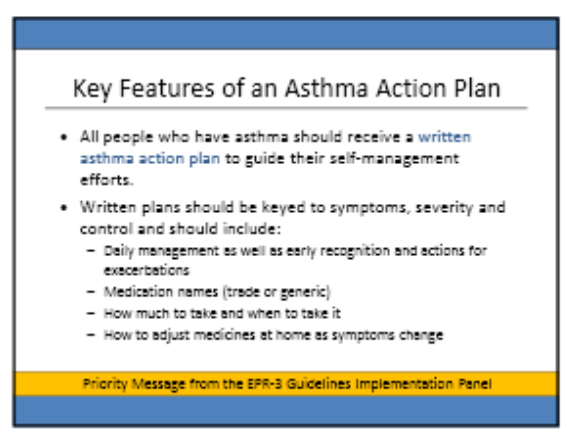
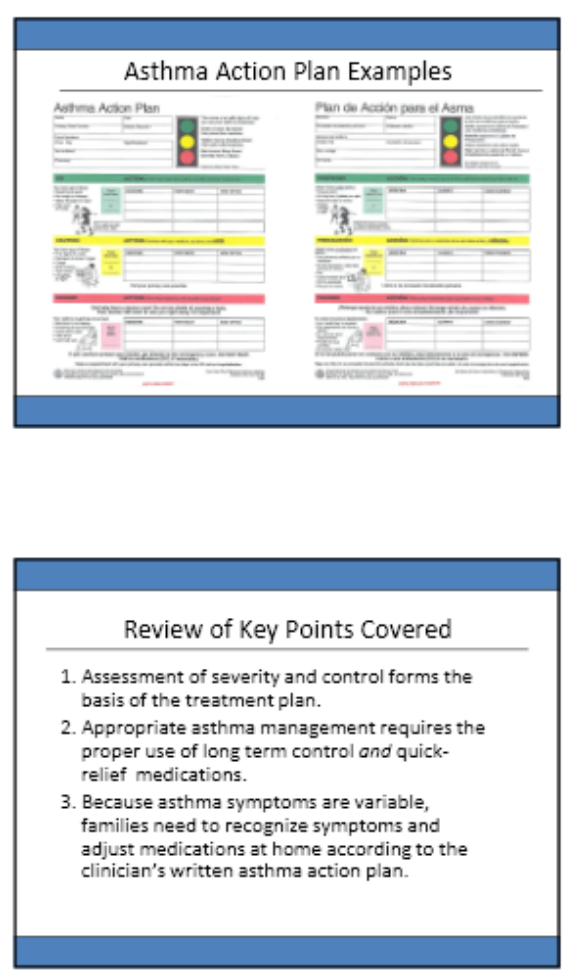
Appendix E

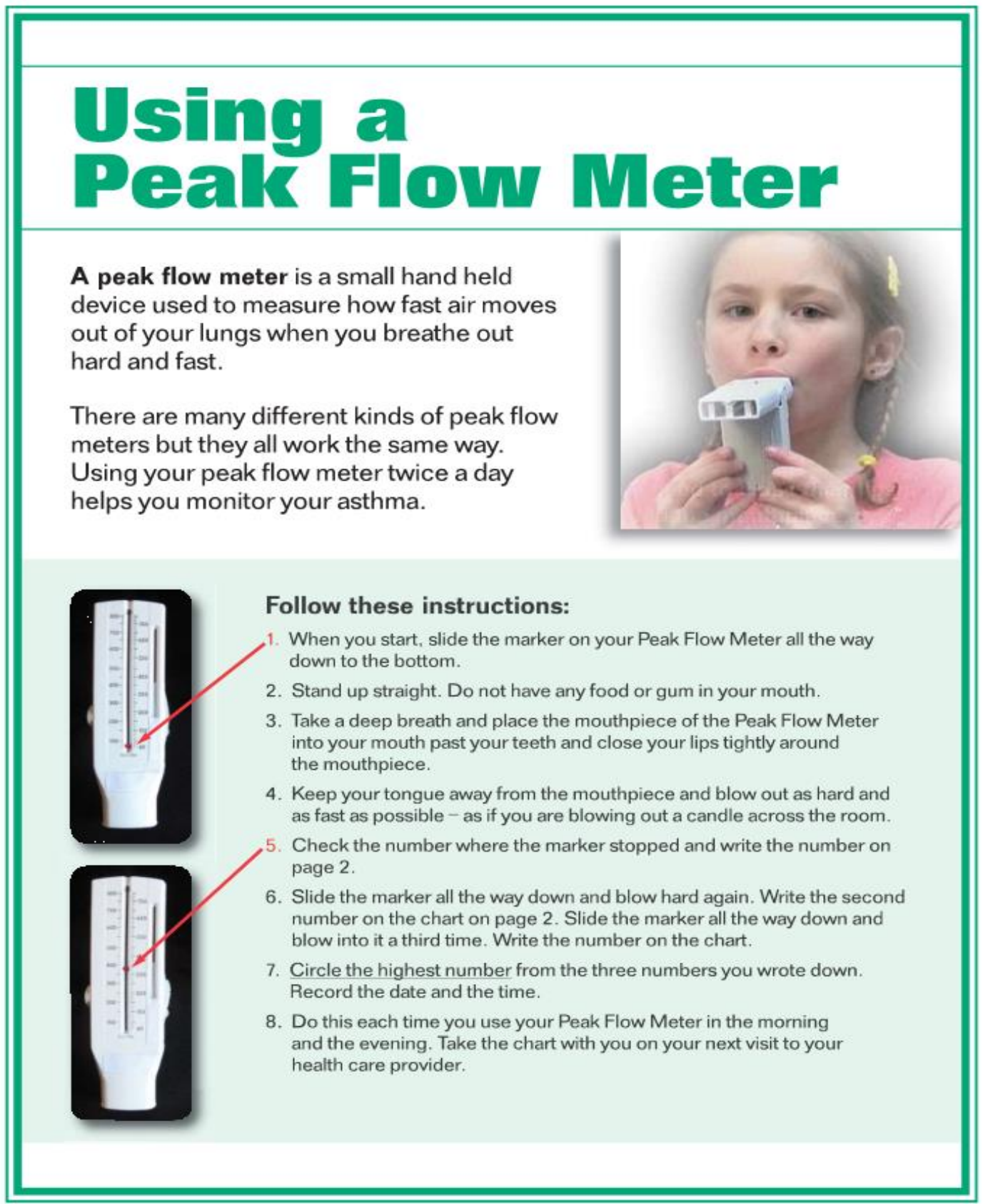


Peak Flow Meter Chart - Week 1

PAGE 2

\begin{tabular}{|l|c|c|c|c|c|c|c|c|}
\hline Morning & Example & Day 1 & Day 2 & Day 3 & Day 4 & Day 5 & Day 6 & Day 7 \\
\hline Date & May 15 & & & & & & & \\
\hline Time & $7: 00$ am & & & & & & & \\
\hline 1st number & 360 & & & & & & & \\
\hline 2nd number & 380 & & & & & & & \\
\hline 3rd number & 370 & & & & & & & \\
\hline
\end{tabular}

Circle the highest number

Peak Flow Meter Chart - Week 1

\begin{tabular}{|l|c|c|c|c|c|c|c|c|}
\hline Evening & Example & Day 1 & Day 2 & Day 3 & Day 4 & Day 5 & Day 6 & Day 7 \\
\hline Date & May 15 & & & & & & & \\
\hline Time & $7: 00 \mathrm{pm}$ & & & & & & & \\
\hline 1st number & 360 & & & & & & & \\
\hline 2nd number & $(380)$ & & & & & & & \\
\hline 3rd number & 370 & & & & & & & \\
\hline
\end{tabular}

Circle the highest number

\section{Peak Flow Meter Chart - Week 2}

\begin{tabular}{|l|l|l|l|l|l|l|l|}
\hline Morning & Day 8 & Day 9 & Day 10 & Day 11 & Day 12 & Day 13 & Day 14 \\
\hline Date & & & & & & & \\
\hline Time & & & & & & & \\
\hline 1st number & & & & & & & \\
\hline 2nd number & & & & & & & \\
\hline 3rd number & & & & & & & \\
\hline
\end{tabular}

Circle the highest number

Peak Flow Meter Chart - Week 2

\begin{tabular}{|l|l|l|l|l|l|l|l|}
\hline Evening & Day 8 & Day 9 & Day 10 & Day 11 & Day 12 & Day 13 & Day 14 \\
\hline Date & & & & & & & \\
\hline Time & & & & & & & \\
\hline 1st number & & & & & & & \\
\hline 2nd number & & & & & & & \\
\hline 3rd number & & & & & & & \\
\hline
\end{tabular}

Circle the highest number

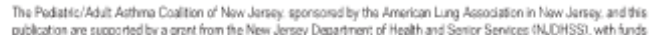

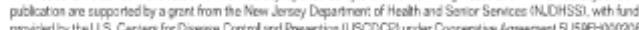

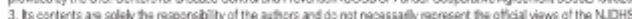

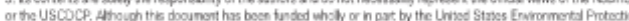

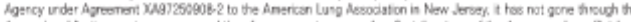

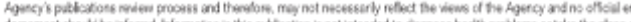

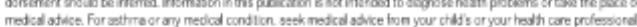

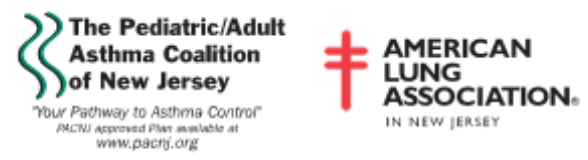




\section{Appendix F}

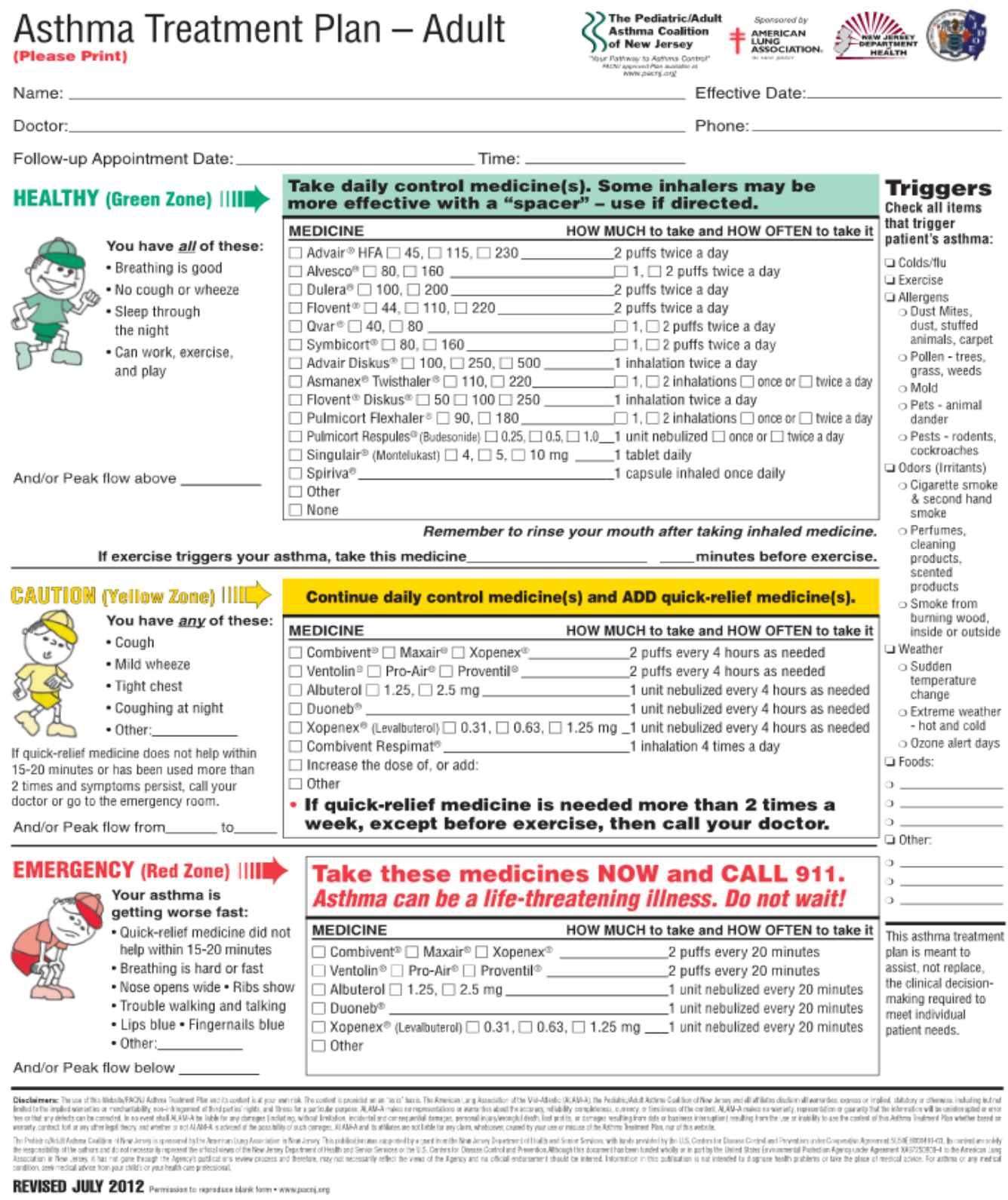




\section{Appendix G}

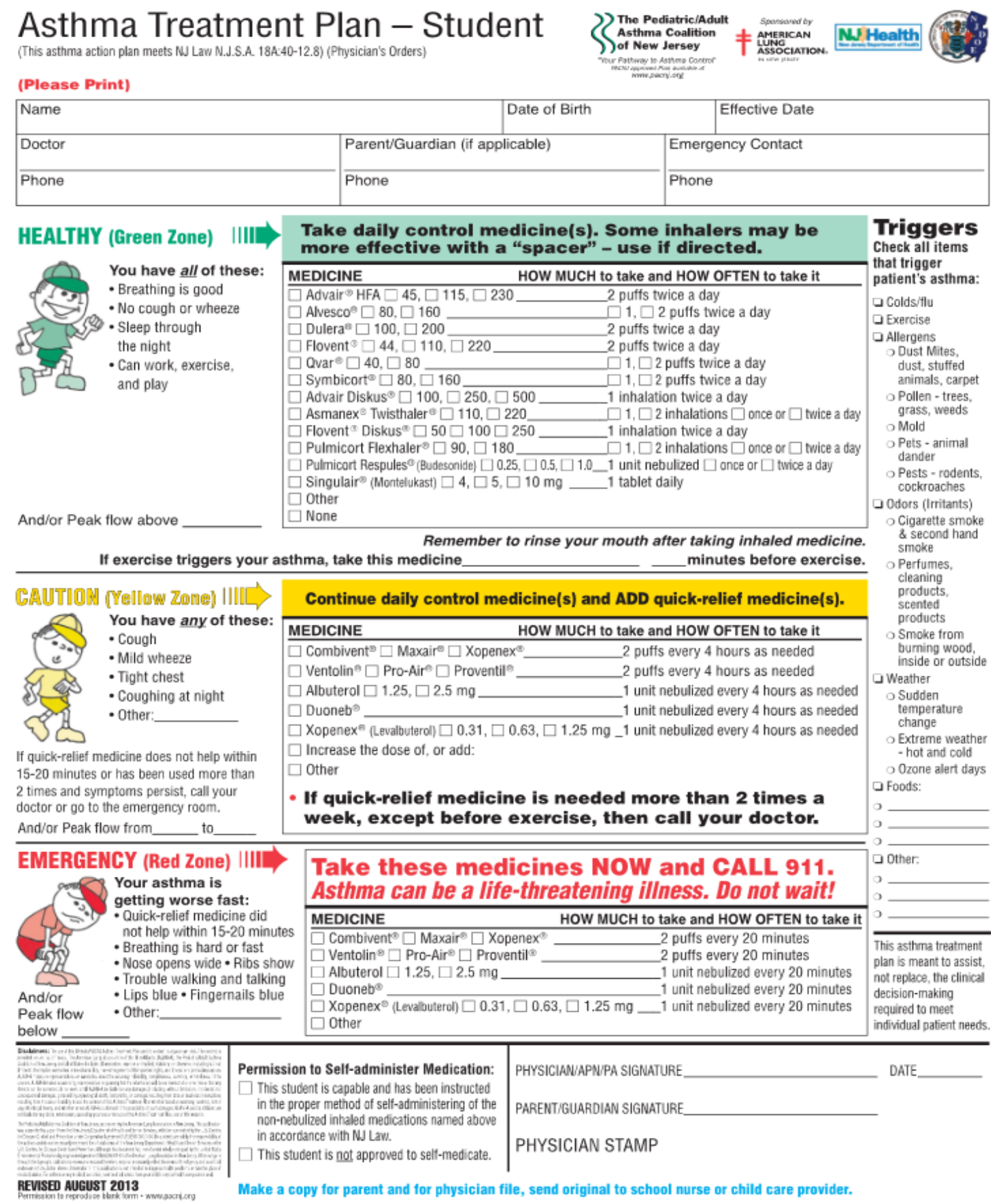




\section{Appendix $\mathbf{H}$}

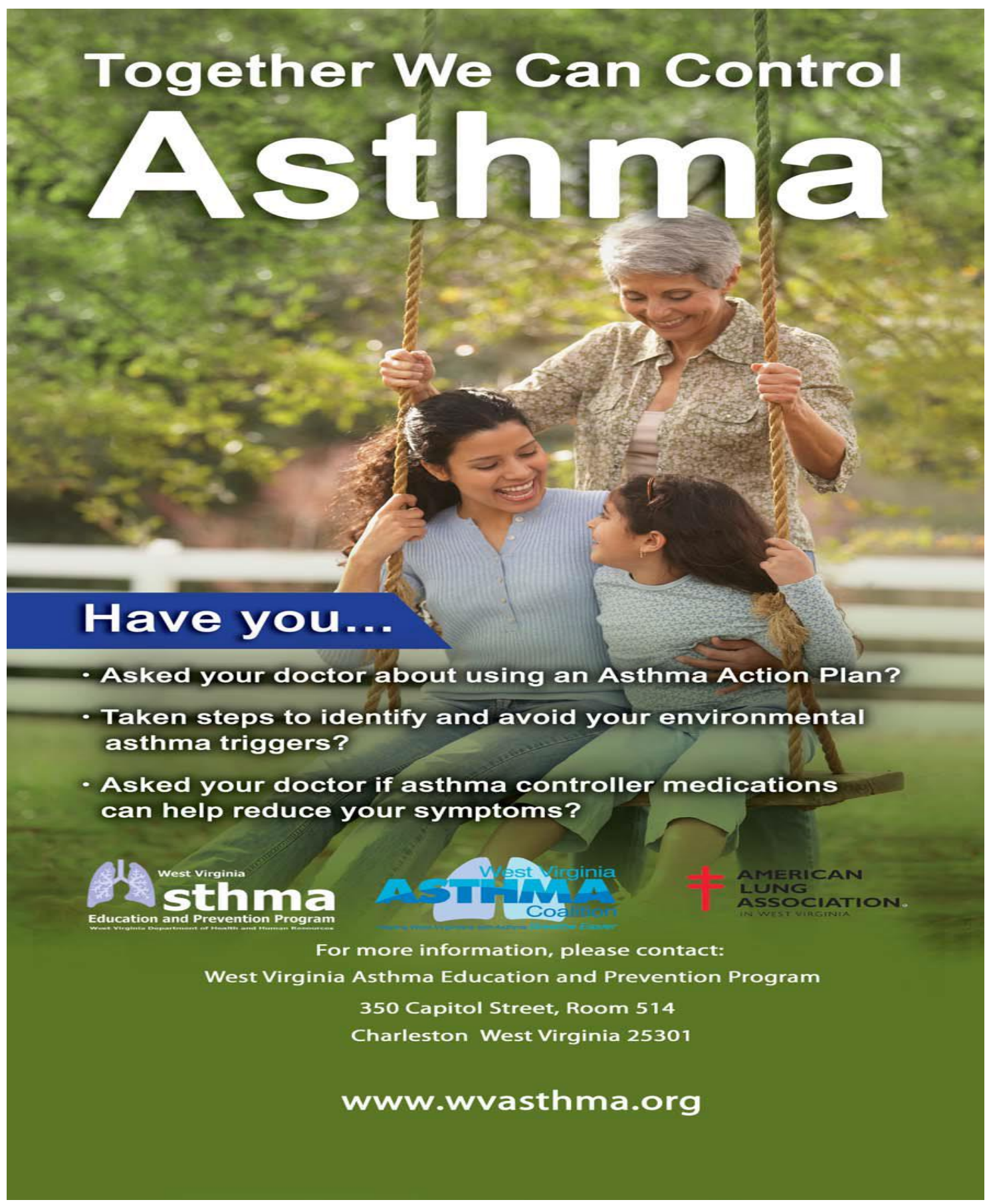


Appendix I

\section{Post-Chart Review}

\begin{tabular}{|c|c|c|c|c|c|}
\hline $\begin{array}{c}\text { Patient Chart ID } \\
\text { Number }\end{array}$ & Age & $\begin{array}{c}\text { Diagnosis Codes Used } \\
\text { During Encounter }\end{array}$ & $\begin{array}{l}\text { Diagnosis Codes } \\
\text { Omitted During } \\
\text { Visit }\end{array}$ & $\begin{array}{c}\text { *Action Plan in Chart Last } 6 \\
\text { Weeks Post Education } \\
\text { Y (Yes) or N (No) }\end{array}$ & $\begin{array}{c}\text { Provider/Nurse } \\
\text { Code Letter }\end{array}$ \\
\hline & & & & & \\
\hline & & & & & \\
\hline & & & & & \\
\hline & & & & & \\
\hline & & & & & \\
\hline & & & & & \\
\hline & & & & & \\
\hline & & & & & \\
\hline
\end{tabular}

*ID variables in the provider note: Peak flow; symptom severity, medications (frequency and dosage), documentation of triggers, patient education; plan adjustment. The asthma diagnosis codes and asthma related diagnosis codes are included on next sheet. 


\section{Appendix J}

Budget Plan Form and Justification List funds requested for each category including a reasonable justification for expenses. Include total amount of in-kind contributions, if any, for each category.

\begin{tabular}{|c|c|c|}
\hline Budget Categories & Requested Funds & In-Kind Contributions \\
\hline ADMINSTRATIVE COSTS & $\$ 0.00$ & Direct Costs: $\$ 4422.32$ \\
\hline \multicolumn{3}{|c|}{$\begin{array}{l}\text { Cost of operating clinic for } 60 \text { minutes providers and nurses in education session (no patients } \\
\text { scheduled) at onset of project. } 11 \text { clinical staff x } 60 \text { minutes }=\$ 245.10 \times 2 \text { sessions }=\$ 490.20 \\
\text { There will be no decrease in scheduled number of patients seen daily. The providers will } \\
\text { incorporate the action plans into their routine visits. } \\
\text { Cost for project leader to organize program, conduct chart audits, and examine process ( } 4 \text { hrs weekly } \\
\times 24 \text { weeks } \times 337 / \mathrm{hr}=\$ 3552) \\
\text { Team leader cost to copy action plans and oversee project }(\$ 15.00 / \mathrm{hr} \times 1 \mathrm{hrs} / \text { week } \times 24 \\
\text { weeks }=\$ 360.00\end{array}$} \\
\hline MARKETING & $\$ 0.00$ & $\$ 0.00$ \\
\hline \multicolumn{3}{|c|}{$\begin{array}{l}\text { Marketing justification: There will be reminder posters placed in the lunch room on filling out } \\
\text { action plans }(\$ 0.06 \times 1 \times 6 \text { months }=\$ 0.36)\end{array}$} \\
\hline $\begin{array}{l}\text { EDUCATIONAL MATERIALS/ } \\
\text { INCENTIVES }\end{array}$ & $\$ 0.00$ & $\$ 20.12$ \\
\hline
\end{tabular}

Educational Materials/Incentives Justification:

Asthma action plans can be printed for free from http://www.pacnj.org/plan.html

Ream of paper $/ 500$ sheets, cost $\$ 3.29$ (would require 2 reams) $=\$ 6.58$

Toner black and white printer $\$ 81.00$ /yields approximately 10,000 pages (cost per sheet $\$ 0.0081$ )

Toner for color printer $\$ 80.00$ per cartridge $\mathrm{x} 4$ cartridges, yield approximately 8,000 pages (cost per sheet is \$0.04): action plans will be printed from color ink. $(\$ 0.04 \times 200=\$ 8.00)$

Together We Can Control Asthma Poster, WV, requested 5 posters for patient room doors.

(http://www.wvasthma.org/ASTHMAMANAGEMENT/ForHealthcareProviders/tabid/1805/Default. aspx: No cost per NAEPP

Requested 10 Asthma Trifold Guidelines to provide to providers.

http://www.wvasthma.org/ASTHMAMANAGEMENT/ForHealthcareProviders/tabid/1805/Default. aspx No cost per NAEPP

PACE educational material for clinicians (65 pages x 10 participants $\times \$ 0.0081=\$ 5.79$ )

Peak flow meter education (2 pages x 11 participants $\times \$ 0.0081=\$ 0.17$ )

Power point projector (no charge, located at clinic)

Power points from PACE (no charge)

Binders $(\$ 3.79 / 5$ pack x $2=\$ 7.58)$ 


\begin{tabular}{|c|c|c|}
\hline $\begin{array}{l}\text { HOSPITALITY (food, room rentals, } \\
\text { etc.) }\end{array}$ & $\$ 0.00$ & $\$ 0.00$ \\
\hline \multicolumn{3}{|c|}{$\begin{array}{l}\text { Hospitality justification: Project will take place during regular patient treatment in patient rooms, } \\
\text { room in kind from Coplin clinic. }\end{array}$} \\
\hline $\begin{array}{l}\text { PROJECT SUPPLIES (office } \\
\text { supplies, postage, printing, etc.) }\end{array}$ & $\$ 0.00$ & $\$ 0.00$ \\
\hline \multicolumn{3}{|c|}{$\begin{array}{l}\text { Project supplies justification: Printing of educational material is included in educational } \\
\text { materials/incentives. }\end{array}$} \\
\hline PATIENT CARE & $\$ 0.00$ & $\$ 0.00$ \\
\hline \multicolumn{3}{|l|}{ Patient Care justification: } \\
\hline TRAVEL EXPENSES & $\$ 0.00$ & $\$ 0.00$ \\
\hline \multicolumn{3}{|c|}{ Travel expenses justification: There will be no travel involved. } \\
\hline TOTALS & $\$ 0.00$ & Direct Costs: $\$ 4421.78$ \\
\hline
\end{tabular}


Appendix K

Work Plan Form (Use this form, adding rows as needed. You may submit a maximum of four pages for this section.)

Project Goals: To lead and evaluate the organizational process change in the care of patients with asthma by changing provider and nursing staff behavior to enable care of patients with asthma through the use of asthma action plans annually.

\begin{tabular}{|c|c|c|c|c|c|}
\hline *SMART Objective & Activities & $\begin{array}{l}\text { Projected } \\
\text { Completion } \\
\text { Date }\end{array}$ & $\begin{array}{l}\text { Projected } \\
\text { Number of } \\
\text { People Reached }\end{array}$ & $\begin{array}{l}\text { Organization(s)/ } \\
\text { Partner(s) } \\
\text { collaborating with } \\
\text { to conduct activity }\end{array}$ & $\begin{array}{l}\text { Evaluation Plan (Describe } \\
\text { measures used to assess } \\
\text { satisfaction, project } \\
\text { outcomes, benefits, etc.) }\end{array}$ \\
\hline $\begin{array}{l}\text { By Aug. 1, } 2013 \\
\text { leadership team will be } \\
\text { developed including } \\
\text { CEO, DCS SMD. } \\
\text { Patients with asthma } \\
\text { will be identified } \\
\text { including how many } \\
\text { have been seen in the } \\
\text { last } 6 \text { months. }\end{array}$ & $\begin{array}{l}\text { *Evaluate funding and } \\
\text { develop a budget. } \\
\text { *Discuss timeline with } \\
\text { champions. } \\
\text { *Evaluate patient census } \\
\text { reports }\end{array}$ & Aug.1, 2013 & 5 & $\begin{array}{l}\text { Coplin Clinic CEO } \\
\text { MD } \\
\text { Project team leader } \\
\text { Chair/committee }\end{array}$ & $\begin{array}{l}\text { Agreement on program } \\
\text { Emails confirming } \\
\text { acceptance of program. } \\
\text { Completed audit of patient } \\
\text { census reports. }\end{array}$ \\
\hline $\begin{array}{l}\text { By September 16, } 2013 \\
\text { the IRB process will be } \\
\text { implemented. }\end{array}$ & $\begin{array}{l}\text { *Meet with project Chair } \\
\text { to evaluate process change. } \\
\text { *Discuss timeline changes } \\
\text { with Chair. } \\
\text { *Send proposal to clinical } \\
\text { expert for review. } \\
\text { *Revise proposal as } \\
\text { indicated } \\
\text { Begin IRB process }\end{array}$ & $\begin{array}{l}\text { Sept. 23, } \\
2013\end{array}$ & 4 & $\begin{array}{l}\text { Chair/committee } \\
\text { IRB }\end{array}$ & $\begin{array}{l}\text { Emails and phone meetings } \\
\text { to evaluate readiness of } \\
\text { proposal and revise if } \\
\text { needed. } \\
\text { Forms for IRB will be } \\
\text { completed and reviewed by } \\
\text { Chair and committee. }\end{array}$ \\
\hline
\end{tabular}




\begin{tabular}{|c|c|c|c|c|c|}
\hline $\begin{array}{l}\text { By October 15, } 2013 \text { an } \\
\text { asthma education } \\
\text { packet will be } \\
\text { constructed from } \\
\text { educational materials } \\
\text { that have been } \\
\text { compiled to be given to } \\
\text { team players and team } \\
\text { leaders. }\end{array}$ & $\begin{array}{l}\text { *Develop asthma education } \\
\text { packet utilizing patient } \\
\text { education from PACE and } \\
\text { NAEPP. } \\
\text { * WVAEPP posters and } \\
\text { provider education } \\
\text { brochure received and } \\
\text { added to packets. }\end{array}$ & $\begin{array}{l}\text { Oct. 15, } \\
2013\end{array}$ & 5 & $\begin{array}{l}\text { Coplin Clinic CEO } \\
\text { MD } \\
\text { Project team leader }\end{array}$ & $\begin{array}{l}\text { Education packet will be } \\
\text { constructed and material } \\
\text { will be placed in binders } \\
\text { for team players and team } \\
\text { leader. } \\
\text { Posters will be taken to } \\
\text { clinic. }\end{array}$ \\
\hline $\begin{array}{l}\text { By Nov. } 7 \text { and } 14,2013 \\
\text { providers and nursing } \\
\text { staff will attend } \\
\text { monthly staff meeting. }\end{array}$ & $\begin{array}{l}\text { *Participants will be } \\
\text { informed of class } 1 \text { week } \\
\text { prior to meeting. } \\
\text { *Packets will be completed } \\
\text { for educational in-service. }\end{array}$ & $\begin{array}{l}\text { Nov 14, } \\
2013\end{array}$ & 10 & $\begin{array}{l}2 \text { medical doctors } \\
\text { including medical } \\
\text { director } \\
2 \text { physician } \\
\text { assistants } \\
1 \text { nurse practitioner } \\
\text { CMC } \\
\end{array}$ & $\begin{array}{l}\text { Sign in sheet will be } \\
\text { provided during in-service. } \\
\text { After in-service, sheet will } \\
\text { be evaluated. }\end{array}$ \\
\hline $\begin{array}{l}\text { By Dec. } 2,2013 \text { change } \\
\text { process will be } \\
\text { implemented in the } \\
\text { clinic. }\end{array}$ & $\begin{array}{l}\text { *Process change will be } \\
\text { handed to team players for } \\
\text { implementation. } \\
\text { *6 week process change } \\
\text { started. }\end{array}$ & $\begin{array}{l}\text { Jan. 15, } \\
2013\end{array}$ & 12 & $\begin{array}{l}\text { Any staff present on } \\
\text { day of initiation } \\
\text { through first month } \\
\text { of process change }\end{array}$ & $\begin{array}{l}\text { Team leader will evaluate } \\
\text { process change and copy } \\
\text { action plans as needed. }\end{array}$ \\
\hline $\begin{array}{l}\text { By Jan. 15, 2014, } \\
\text { Process change will } \\
\text { conclude. }\end{array}$ & $\begin{array}{l}\text { *Project leader will begin } 6 \\
\text { week post process change } \\
\text { chart audit } \\
\text { *Data will be collected and } \\
\text { analyzed. }\end{array}$ & $\begin{array}{l}\text { Mar.15, } \\
2014\end{array}$ & 1 & $\begin{array}{l}\text { Capstone project } \\
\text { leader }\end{array}$ & $\begin{array}{l}\text { Chart audit will be } \\
\text { completed on all patients } \\
\text { seen in last } 6 \text { weeks with a } \\
\text { diagnosis of asthma/asthma } \\
\text { related. } \\
\text { Data will be analyzed. }\end{array}$ \\
\hline $\begin{array}{l}\text { By Apr. 15, } 2014 \text { have } \\
\text { dissemination of data } \\
\text { and defend capstone }\end{array}$ & $\begin{array}{l}\text { *Chart audit reports } \\
\text { *Statistical analysis of } \\
\text { outcomes }\end{array}$ & $\begin{array}{l}\text { Apr. 15, } \\
2014\end{array}$ & 15 & $\begin{array}{l}\text { Coplin Clinic CEO } \\
\text { Team players } \\
\text { Capstone project }\end{array}$ & $\begin{array}{l}\text { Final report will be } \\
\text { presented } \\
\text { Outcomes will be provided }\end{array}$ \\
\hline
\end{tabular}




\begin{tabular}{|l|l|l|l|l|}
\hline project. & $\begin{array}{l}\text { *Approval of defense of } \\
\text { capstone project. } \\
\text { *Notify staff and } \\
\text { administration of } \\
\text { outcomes. }\end{array}$ & & $\begin{array}{l}\text { leader } \\
\text { Chair and } \\
\text { committee }\end{array}$ \\
\hline
\end{tabular}

*SMART is a simple acronym used to set objectives. It stands for: 1. Specific - Objectives should specify what they want to achieve; 2 . Measurable - You should be able to measure if you are meeting the objectives or not; 3 . Acchievable - Are the objectives you set, achievable and attainable; 4.

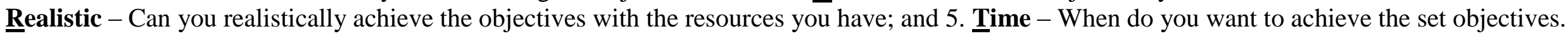

- List all objectives, activities, and/or resources that will be used to help you reach your goals. For each activity, include the projected completion dates of activities and the number of people that you will reach. Summarize what will occur and where it will take place

- In the Evaluation Plan column, list all the measures and tools you will use. Evaluation plans will depend on the project's proposed activities. At a minimum you should (1) evaluate participant satisfaction with your activities and (2) demonstrate how your activities have benefited the participants. Copies of evaluation materials must be included in your proposal, may include surveys, participant satisfaction, pre-post tests to measure knowledge gained by participants.

(Mountains of Hope mini-grant evaluation) 


\section{Appendix L}

\section{Time Line}

\begin{tabular}{|c|c|c|c|c|c|c|c|c|c|c|c|c|c|c|}
\hline \multirow[t]{2}{*}{ Task } & \multicolumn{8}{|c|}{2013} & \multicolumn{6}{|c|}{2014} \\
\hline & May & Jun & Jul & Aug & Sep & Oct & Nov & Dec & Jan & Feb & Mar & Apr & May & Jun \\
\hline $\begin{array}{l}\text { Evaluate } \\
\text { funding } \\
\text { Discuss } \\
\text { timeline } \\
\text { Evaluate } \\
\text { patient } \\
\text { census data }\end{array}$ & & & & & & & & & & & & & & \\
\hline $\begin{array}{l}\text { Implement } \\
\text { IRB process } \\
\text { and obtain } \\
\text { approval of } \\
\text { capstone } \\
\text { project }\end{array}$ & & & & & & & & & & & & & & \\
\hline $\begin{array}{l}\text { Pre audit } \\
\text { chart } \\
\text { Finish } \\
\text { education } \\
\text { packets } \\
\text { Educate staff } \\
\text { on guidelines }\end{array}$ & & & & & & & & & & & & & & \\
\hline $\begin{array}{l}\text { Implement } \\
\text { process } \\
\text { change }\end{array}$ & & & & & & & & & & & & & & \\
\hline $\begin{array}{l}6 \text { week post } \\
\text { audit of } \\
\text { patient charts } \\
\text { Data } \\
\text { collection and } \\
\text { analysis }\end{array}$ & & & & & & & & & & & & & & \\
\hline
\end{tabular}




\section{Appendix M}

\begin{tabular}{|c|c|c|}
\hline Questions & Pretest \% Correct & Posttest \% Correct \\
\hline $\begin{array}{l}\text { 1. Appropriate asthma } \\
\text { management requires } \\
\text { the proper use of... }\end{array}$ & $100 \%$ & $87.5 \%$ \\
\hline $\begin{array}{l}\text { 2. Provider should } \\
\text { review the asthma } \\
\text { action plan... }\end{array}$ & $100 \%$ & $100 \%$ \\
\hline $\begin{array}{l}\text { 3. Asthma action plans } \\
\text { should only include } \\
\text { medication names but } \\
\text { no doses.. }\end{array}$ & $100 \%$ & $100 \%$ \\
\hline $\begin{array}{l}\text { 4. All patients should } \\
\text { have an initial severity } \\
\text { assessment based on... }\end{array}$ & Omitted & Omitted \\
\hline $\begin{array}{l}\text { 5. Name } 2 \text { benchmarks } \\
\text { of good asthma control }\end{array}$ & $20 \%$ & $50 \%$ \\
\hline
\end{tabular}




\section{References}

Agree II instrument (May 2009). Canadian Institute of Health Research. Retrieved from www.sign.ac.uk/methodology/agreeguide/index.html

Akinbami, L. (2006). The State of childhood asthma, United States, 1980-2005. Advance data from vital and health statistics; no 381, Hyattsville, MD: National Center for Health Statistics.

Akinbami, L., Moorman, J., \& Liu, X. (2011). Asthma Prevalence, Health Care Use, and Mortality: United States, 2005-2009. National health statistics reports; no 32. Hyattsville, MD: National Center for Health Statistics.

American Academy of Allergy Asthma and Immunology (2013). Retrieved from Website: http://www.aaaai.org/about-the-aaaai/newsroom/asthma-statistics.aspx

American Lung Association (2012). Trends in Asthma Morbidity and Mortality. Retrieved from Website: http://www.lung.org/finding-cures/our-research/trend-reports/asthma-trendreport.pdf

American Lung Association of New Jersey (2013). Asthma Action Plan. Retrieved from Website: http://www.pacnj.org/plan.html

Bartholomew, L., Sockrider, M., Abramson, S., Swank, P., Czyzewski, D., Tortolero, S., \& ... Tyrrell, S. (2006). Partners in school asthma management: evaluation of a selfmanagement program for children with asthma. Journal of School Health, 76(6), 283290. doi:10.1111/j.1746-1561.2006.00113.x

Brown, R., Bratton, S., Cabana, M., Kaciroti, N., \& Clark, N. (2004). Physician asthma education program improves outcomes for children of low-income families. Chest, 126(2), 369-374. 
Burkhart, P. V., Rayens, M., Revelette, W., \& Ohlmann, A. (2007). Improved Health Outcomes with Peak Flow Monitoring for Children with Asthma. Journal Of Asthma, 44(2), 137142. doi:10.1080/02770900601182517

Camargo, C. R., Reed, C. R., Ginde, A. A., Clark, S., Emond, S. D., \& Radeos, M. S. (2008). A prospective multicenter study of written action plans among emergency department patients with acute asthma. Journal of Asthma, 45(7), 532-538. doi:10.1080/02770900801978573

Centers for Disease Control and Prevention. Asthma's Impact on the Nation. 2012. Atlanta, GA: U.S. Retrieved from CDC website: http://www.cdc.gov/asthma/impacts_nation/AsthmaFactSheet.pdf

Dexheimer, J., Talbot, T., Sanders, D., Rosenbloom, S., \& Aronsky, D. (2008). Prompting clinicians about preventative care measures: A systematic review of randomized controlled trials. Journal of the American Medical Informatics Association, 15(3), 311-319.

Feldstein, A., Elmer, P., Smith, D., Herson, M., Orwoll, E., Chen, C., \& ... Swain, M. (2006). Electronic medical record reminder improves osteoporosis management after a fracture: a randomized, controlled trial. Journal Of The American Geriatrics Society, 54(3), 450457. doi:10.1111/j.1532-5415.2005.00618.x

Halterman, J., Fisher, S., Conn, K., Fagnano, M., Lynch, K., Marky, A., \& Szilagyi, P. (2006). Improved preventive care for asthma: a randomized trial of clinician prompting in pediatric offices. Archives Of Pediatrics \& Adolescent Medicine, 160(10), 1018-1025. 
Huang, T., Li, Y., \& Wang, C. (2009). Individualized programme to promote self-care among older adults with asthma: randomized controlled trial. Journal Of Advanced Nursing, 65(2), 348-358. doi:10.1111/j.1365-2648.2008.04874.x

Kotter, J. (1995). Leading change: Why transformation efforts fail. Harvard Business Review, March-April, 59-67.

Kotter, J. (2012). Leading Change. Boston, Massachusetts: Harvard Business Review Press.

Larrabee, J.H. (2009). Nurse to Nurse: Evidence-Based Practice. New York, NY: McGraw-Hill, Measures of asthma assessment and monitoring. National Asthma Education and Prevention Program (NAEPP). Expert panel report 3: guidelines for the diagnosis and management of asthma. Bethesda (MD): National Heart, Lung, and Blood Institute; 2007 Aug. p. 3692. [134 references]

National Heart, Lung, and Blood Institute (NHLBI). Physician Asthma Care Education (PACE). 2013. Retrieved from: htttp://www.nhlbi.nih.gov/health/prof/lung/asthma/pace/resources.htm

Ockene, J \& Zapka, J. (2000). Provider education to promote implementation of clinical practice guidelines. Chest 188(2), 33S-39S.

Scottish Intercollegiate Guidelines Network (2009). Critical Appraisal: Notes and Checklist. [on line]. Available: http://www.sign.ac.uk/methodology/checklists.html

Sockrider, M., Abraham, S., Brooks, E., Caviness, A., Pilney, S., Koerner, C., \& Macias, C. (2006). Delivering tailored asthma family education in a pediatric emergency department setting: a pilot study. Pediatrics, 117(4), S135-44.

Sullivan, S., Lee, T., Blough, D., Finkelstein, J., Lozano, P., Inui, T., \& ... Weiss, K. (2005). A multisite randomized trial of the effects of physician education and organizational change 
in chronic asthma care: cost-effectiveness analysis of the Pediatric Asthma Care Patient Outcomes Research Team II (PAC-PORT II). Archives Of Pediatrics \& Adolescent Medicine, 159(5), 428-434.

West Virginia Asthma Education and Prevention Program (WV-AEPP). Asthma in West Virginia Fact Sheet. October 2012. Retrieved from:

http://www.wvasthma.org/Portals/4/Asthma\%20in\%20WV\%20Fact\%20Sheet\%2010181 $2 \% 20(2) \cdot p d f$

West Virginia Department of Health and Human Resources (2007). The Burden of Asthma in WV. Bureau for Public Health. Retrieved from http://www.wvasthma.org/Portals/4/Final\%202007\%20Asthma\%20Burden\%20Report\% 2010-12-07.pdf.

Wirt County Health Services Association (WCHSA) Benchmark Data, Mission Statement, and Values (2013).

Wolf F, Guevara JP, Grum CM, Clark NM, Cates CJ. Educational interventions for asthma in children. Cochrane Database of Systematic Reviews 2002, Issue 4. Art. No.: CD000326. DOI: $10.1002 / 14651858 . C D 000326$.

Zemek, R., Bhogal, S., \& Ducharme, F. (2008). Systematic review of randomized controlled trials examining written action plans in children: what is the plan?. Archives Of Pediatrics \& Adolescent Medicine, 162(2), 157-163. 